\title{
Nutrients, emerging pollutants and pesticides in a tropical urban reservoir: Spatial distributions and risk assessment
}

\author{
Julio C. López-Doval a,b,*, Cassiana C. Montagner ${ }^{c}$, Anjaína Fernandes de Alburquerque ${ }^{\mathrm{d}}$, \\ Viviane Moschini-Carlos ${ }^{\mathrm{e}}$, Gisela Umbuzeiro ${ }^{\mathrm{c}}$, Marcelo Pompêo ${ }^{\mathrm{a}}$ \\ a Institute of Biosciences, Department of Ecology, University of São Paulo, Rua do Matão, Travessa 14, 321, Butantã, 05508-090 São Paulo, SP, Brazil \\ b Department of Evolutionary Biology, Ecology and Environmental Sciences, University of Barcelona, Avinguda Diagonal, 643,08028 Barcelona, Spain \\ ' Institute of Chemistry, University of Campinas, PO Box 6154, 13084-971 Campinas, SP, Brazil \\ d School of Technology, University of Campinas, Rua Paschoal Marmo 1888, 13484-332 Limeira, Brazil \\ e São Paulo State University -UNESP, Environmental Sciences Program, Avenida Três de Março 511, 18087-180 Sorocaba, SP, Brazil
}

\section{H I G H L I G H T S}

- Information on behavior and presence of emerging pollutants in reservoirs is scarce.

- Chemical quality of a tropical urban reservoir was monitored.

- High levels of eutrophy, emerging pollutants (EPs) and pesticides were detected.

- Spatial and seasonal patterns were described for pesticides and EPs.

- Three compounds showed possible risk for biota.

\section{G R A P H I C A L A B S T R A C T}

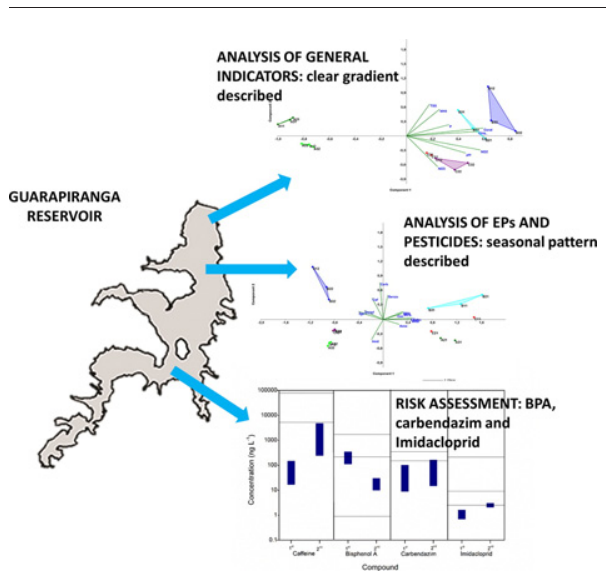

\begin{abstract}
A B S T R A C T
Reservoirs located in urban areas suffer specific pressures related to human activities. Their monitoring, management, and protection requirements differ from reservoirs situated in non-urbanized areas. The objectives of this study were: (a) to determine the concentrations of select pesticides and emerging pollutants (EPs) present in an urban reservoir; (b) to describe their possible spatial distributions; and (c) to quantify the risks for aquatic life and safeguard drinking water supplies. For this purpose, the Guarapiranga reservoir was studied as an example of a multi-stressed urban reservoir in a tropical region. A total of 31 organic compounds (including pesticides, illicit drugs, pharmaceuticals, and endocrine disruptors) were analyzed twice over a period of one year, together with classical indicators of water quality. The physical and chemical data were treated using principal component analysis (PCA) to identify possible temporal or spatial patterns. Risk assessment was performed for biota and drinking water use, comparing maximum environmental concentrations (MECs) with the predicted no-effect concentrations (PNECs) or drinking water quality criteria (DWC), respectively. The results demonstrated the presence of pesticides and EPs, as well as pollution by high levels of nutrients and Chlorophyll $a(C h l . a)$, during the study period. The nutrients and Trophic State Index (TSI) showed gradients in the reservoir and regional
\end{abstract}

\footnotetext{
* Corresponding author at: Institute of Biosciences, Department of Ecology, University of São Paulo, Rua do Matão, Travessa 14, 321, Butantã, 05508-090 São Paulo, SP, Brazil. E-mail address: jclopezdoval@usp.br (J.C. López-Doval).
} 
distributions, while the pesticides and EPs only clearly showed this pattern in the dry season. The concentrations and distributions of the pesticides and EPs therefore showed seasonality. These findings suggested that the two groups of pollutants (EPs + pesticides and nutrients) possessed different sources and behavior and were not always correlated in the reservoir studied. In the studied period, no risk was observed in raw water for drinking water use, but carbendazim, imidacloprid, and BPA showed risks for the biota in the reservoir.

(c) 2016 Elsevier B.V. All rights reserved.

\section{Introduction}

Economic, social, and demographic changes around the world have led to growth in water demand and the appearance of new chemical threats to freshwater resources involving emerging pollutants (EPs) (Richardson and Kimura, 2015; Petrovic et al., 2011; Pal et al., 2010) as well as the classical and well-known regulated chemical substances.

Due to growth in water demand, together with increased pollution of aquatic systems in some countries, reservoirs have become strategic to ensure the quality and availability of water, especially in highly urbanized regions (Lehner et al., 2011; Liu et al., 2015). Over 25\% of the global river flow has experienced alteration in order to provide clean water for human purposes (Vörösmarty et al., 2010) and around 850,000 dams are in operation, and more are under construction (Nilsson et al., 2005; Zarfl et al., 2015). In South America, a large number of reservoirs were constructed during the 20th and 21st centuries. These reservoirs play an important role in economic development by supplying water for industry, agriculture, urban consumption, and recreational services (Tundisi et al., 1998).

Land use for urban and industrial purposes is increasing along with growth of urban population. By 2030, approximately $60 \%$ of the projected global population ( 8.3 billion) is expected to live in urban areas (Pickett et al., 2011). These transformations are dramatically affecting ecosystems and watersheds (Paul and Meyer, 2001; Meyer et al., 2005; Pickett et al., 2011). Many freshwater reservoirs are located in (or are influenced by) urban areas and suffer from various pressures related to human activities (Tundisi and Matsumura-Tundisi, 2003). Hence, the monitoring, management and protection of these aquatic systems involve challenges that are relatively new and that are different from those observed for reservoirs situated in non-urbanized areas.

These multiple stressors affecting urban reservoirs include inputs of complex mixtures of pollutants (such as EPs, PAHs, pesticides, nutrients and metals) entering into the reservoir due to surface run-off from roads, street surfaces, green areas and industrial facilities, together with sewage discharges, outflows from wastewater treatment plants, and aerial deposition of substances originated from vehicle exhaust and industrial emissions (including acidic compounds and metals) (Hall and Ellis, 1985; Ellis and Mitchell, 2006; de Morais and Guandique, 2015).

The presence and environmental effects of regulated substances and EPs in freshwater ecosystems have been widely studied (Pal et al., 2010; Murray et al., 2010), but there is less information available concerning their presence and behavior in reservoirs and their potential effects on organisms in these systems (Petrovic et al., 2011). Recent studies have provided information on the presence of regulated pollutants and EPs in the waters of several reservoirs (Palma et al., 2010; Félix-Cañedo et al., 2013; Yan et al., 2014; Wang et al., 2015; González-González et al., 2014; Martinez and Peñuela, 2013; Xue et al., 2005; You et al., 2015; Xu et al., 2011) and other authors have provided evidence of potential effects on organisms living in reservoirs (González-González et al., 2014; Huerta et al., 2013b; Pérez et al., 2010; Palma et al., 2010), but information on the potential impacts of these substances in freshwater reservoirs remain poorly understood.

In many countries, the monitoring of reservoirs by water agencies mainly focuses on the control of eutrophication but the analysis of other regulated substances and EPs is often not included or is not extensive (Begliutti et al., 2007; Hering et al., 2010; Petrovic et al., 2011;
Molozzi et al., 2012; Cunha et al., 2013). For example, the European Water Framework Directive (WFD; ECC, 2000) provides guidance on parameters to be monitored in lakes and reservoirs (mainly nutrients and other basic indicators of trophic state and water quality), but the analysis of many chemical substances is not mandatory.

However, maximum preservation of chemical and biological quality (the minor deviation from the chemical water quality and the biological community that would be expected under conditions of minimal anthropogenic impact) is essential to ensure economic, cultural, and recreational benefits of these systems (Turner and Daily, 2008; Molozzi et al., 2012). For example, urban freshwater reservoirs can provide refuges for threatened fauna in urban landscapes (Clements et al., 2006) or allow economic activities such as aquaculture or fishing (Tundisi et al., 2008) when environmental quality is good. On the other hand, poor environmental quality, such as high levels of nutrients ( $\mathrm{N}$ and $\mathrm{P}$ ), leads to changes in the structure and function of the ecosystem, with negative ecological and economic consequences in freshwater reservoirs (Smith et al., 1999; Moschini-Carlos et al., 2009; Azevedo et al., 2015a, b). Therefore, a good knowledge on chemical profiles of freshwater reservoirs and risks of EPs and substances no commonly included in monitoring programs will contribute to a better preservation of these resources.

The objectives of this exploratory study were: (a) to determine the concentrations of some pesticides and emerging organic pollutants (EPs) such as pharmaceuticals, illicit drugs, and endocrine disrupting compounds present in an urban reservoir (and scarcely studied before), as well as to analyze common water quality parameters; (b) to identify their possible spatial distributions; and (c) to quantify the risks of the pesticides and EPs in terms of the protection of aquatic life and the safeguarding of pre-treatment raw water for drinking use.

In Brazil, the biological and chemical qualities of many reservoirs in the vicinity of urban areas are highly impacted by inflows of untreated wastewater containing these complex mixtures of pollutants (Mariani and Pompêo, 2008; Cardoso-Silva et al., 2016), leading to widespread eutrophication of the water bodies and pollution by organic and inorganic pollutants (Braga et al., 2006; Fontana et al., 2014; Bucci et al., 2015; Souza Beghelli et al., 2016). For this purpose, the Guarapiranga reservoir was used as an example of a multi-stressed urban reservoir in a region with a tropical climate. Several different impacts have diminished the chemical and biological quality of this reservoir (CETESB, 2014, 2015).

\section{Materials and methods}

\subsection{Study site}

The Guarapiranga Reservoir is an urban reservoir in the Metropolitan Region of São Paulo (MRSP, State of São Paulo, Brazil) (Fig. 1), situated in the southern area of the city $\left(23^{\circ} 43^{\prime} \mathrm{S} ; 46^{\circ} 32^{\prime} \mathrm{W} ; 742 \mathrm{~m}\right.$ above sea level). The reservoir lies in a sub-basin of the Alto Tietê Basin, with a drainage area of $631 \mathrm{~km}^{2}$. It was constructed in 1906 for electricity production and is now used for water supply. It is currently the second most important public water supply reservoir in the region, supplying two million people in one of the world's largest urban areas (Fontana et al., 2014). The reservoir is impacted by deforestation, soil erosion, and unregulated settlements (favelas). Urbanized (regular and irregular settlements) areas account for $16.9 \%$ of the sub-basin. 


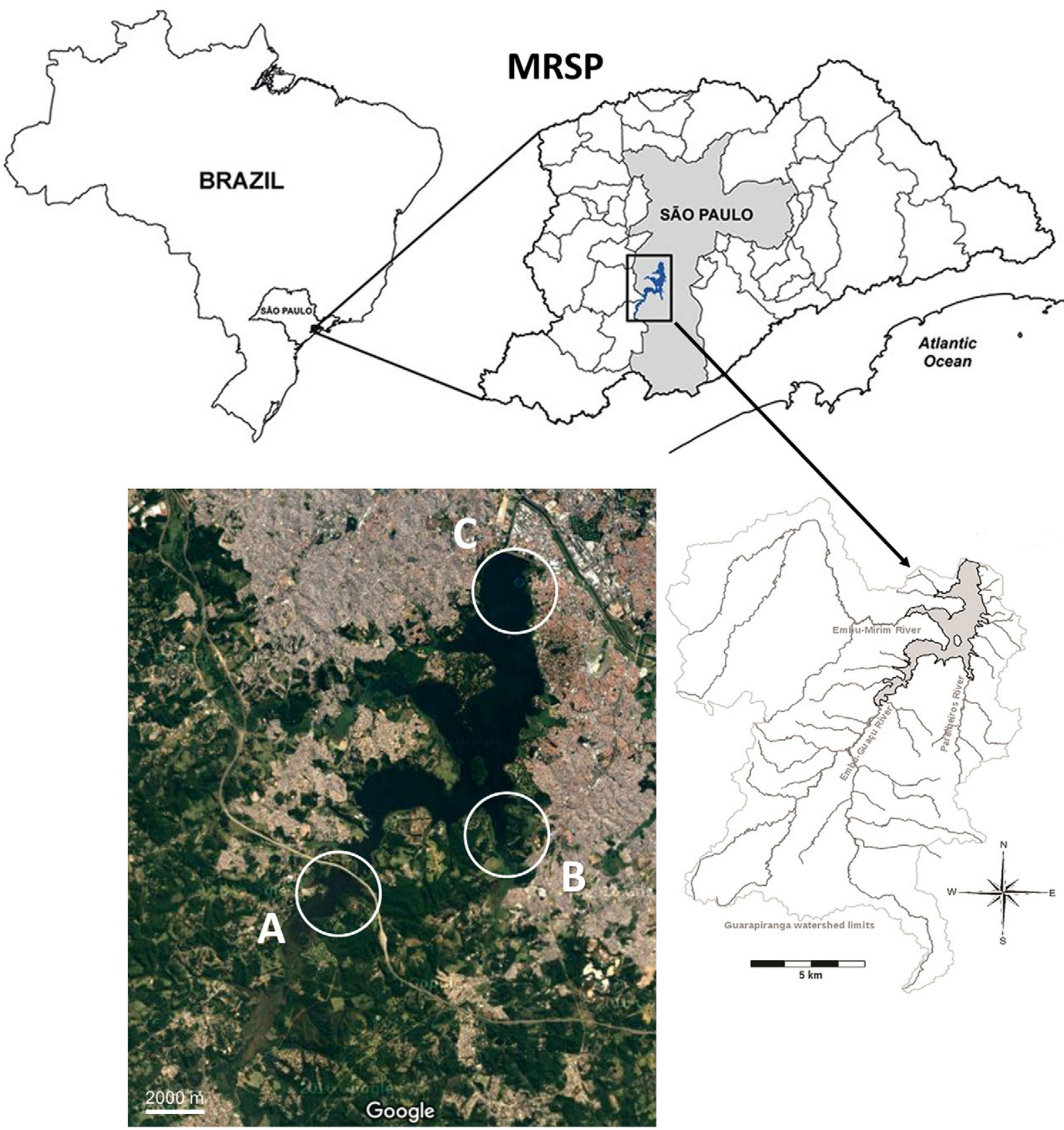

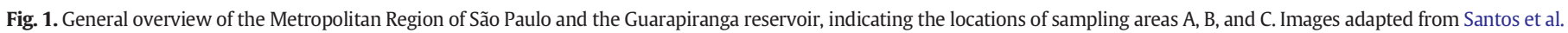
(2015), Faustino et al. (2016) and Google Maps, (c) 2016 CNES/Astrium, Digital Globe (c) 2016 Google.

Agriculture suppose a $4.3 \%$, green areas (such as parks, gardens, waste ground or unmanaged green areas but under anthropic influence) suppose a $30 \%$. The area used for other anthropic purposes (roads, industry, mining activities, landfills...) is $8.1 \%$ (Whately and Cunha, 2006). Pollution inputs to the reservoir are mainly due to runoff from crop, industrial, and urban areas, as well as untreated and treated industrial and domestic effluents (Whately and Cunha, 2006; Cardoso-Silva, 2008; Pompêo et al., 2013). In some of the municipalities and neighborhoods within the Guarapiranga catchment, rates of wastewater collection and treatment are below 50\% (CETESB, 2015; SEADE, 2015), resulting in discharges of untreated sewage into rivers and other water bodies that drain into the Guarapiranga. Due to these long-term inputs of untreated wastewater, the reservoir has been classified as eutrophic since 1960, but can now be considered hyper-eutrophic (Beyruth, 2000; CETESB, 2014). Biological indices indicate impairment of the biological communities in the reservoir (CETESB, 2015).
Three sampling areas in the reservoir were selected in order to cover different possible degrees of pollution (Fig. 1). Area A was located at the Embu-Guaçú River tributary, in a region considered less polluted, with less urban pressure but affected by transportation infrastructures and presence of patches of natural vegetation and agricultural soil. Area B was at the Parelheiros River tributary, where water from another polluted reservoir (the Billings Reservoir) enters the Guarapiranga. This area is surrounded by favelas and patches of natural vegetation and agricultural soil. Area $C$ was situated near the dam, close to the water extraction point and their shores are densely urbanized by favelas, second residences and yacht clubs.

\subsection{Sampling methods}

Two sampling campaigns were performed, in February 2014 (rainy season) and in October 2014 (dry season). It should be noted that 
Table 1

Selected LC-MS/MS experimental parameters for each compound.

\begin{tabular}{|c|c|c|c|c|}
\hline Compounds & $\begin{array}{l}\text { Precursor ion } \\
(m / z)\end{array}$ & $\begin{array}{l}\text { Product ion } \\
(m / z)\end{array}$ & $\begin{array}{l}\text { Collision energy } \\
(\mathrm{eV})\end{array}$ & $\begin{array}{l}\text { ESI } \\
\text { mode }\end{array}$ \\
\hline \multirow[t]{3}{*}{ Caffeine } & \multirow[t]{3}{*}{195.1} & 138.1 & 15 & \multirow[t]{3}{*}{$(+)$} \\
\hline & & 110.1 & 20 & \\
\hline & & 69.1 & 30 & \\
\hline \multirow[t]{2}{*}{ Diclofenac } & 296 & 251.9 & 5 & \multirow[t]{2}{*}{$(-)$} \\
\hline & 294 & 249.9 & 5 & \\
\hline \multirow{3}{*}{$17 \alpha$-ethinylestradiol } & 295 & 144.9 & 30 & \multirow[t]{3}{*}{$(-)$} \\
\hline & & 158.9 & 30 & \\
\hline & & 143.0 & 40 & \\
\hline \multirow[t]{3}{*}{$17 \beta$-estradiol } & 271.1 & 183.0 & 35 & \multirow[t]{3}{*}{$(-)$} \\
\hline & & 144.9 & 30 & \\
\hline & & 143.0 & 40 & \\
\hline Estriol & 287.1 & 170.9 & 30 & $(-)$ \\
\hline & & 144.9 & 35 & \\
\hline & & 143.0 & 40 & \\
\hline Estrone & 269.1 & 144.9 & 30 & $(-)$ \\
\hline & & 143.0 & 40 & \\
\hline & & 182.9 & 35 & \\
\hline Progesterone & 315.3 & 109.1 & 15 & $(+)$ \\
\hline & & 97.2 & 25 & \\
\hline & & 79.2 & 30 & \\
\hline Testosterone & 289.3 & 109.1 & 20 & $(+)$ \\
\hline & & 97.1 & 30 & \\
\hline & & 79.1 & 5 & \\
\hline Triclosan & 289.0 & 37.1 & 5 & $(-)$ \\
\hline & 287.0 & 35.1 & 5 & \\
\hline Bisphenol A & 227 & 132.9 & 25 & $(-)$ \\
\hline & & 210.9 & 30 & \\
\hline Cocaine & 304.1 & 182.1 & 15 & $(+)$ \\
\hline & & 105.0 & 30 & \\
\hline & & 82.1 & 30 & \\
\hline Benzoylecgonine & 290.1 & 168.0 & 15 & $(+)$ \\
\hline & & 105.1 & 30 & \\
\hline & & 82.2 & 30 & \\
\hline Ametryn & 228.2 & 186.1 & 15 & $(+)$ \\
\hline & & 158.1 & 20 & \\
\hline & & 138.1 & 20 & \\
\hline Atrazine & 216.2 & 174.1 & 15 & $(+)$ \\
\hline & & 103.9 & 15 & \\
\hline Simazine & 202.0 & 124.0 & 15 & $(+)$ \\
\hline & & 132.1 & 15 & \\
\hline & & 104.0 & 25 & \\
\hline Azoxystrobin & 404.2 & 372.0 & 5 & $(+)$ \\
\hline & & 344.1 & 20 & \\
\hline Picoxystrobin & 368.2 & 145.0 & 25 & $(+)$ \\
\hline & & 205.0 & 5 & \\
\hline Pyraclostrobin & 388.0 & 163.3 & 10 & $(+)$ \\
\hline & & 194.1 & 20 & \\
\hline Trifloxystrobin & 409.2 & 186.2 & 10 & $(+)$ \\
\hline & & 145.2 & 15 & \\
\hline & & 206.2 & 40 & \\
\hline Bromacil & 261.0 & 205.2 & 10 & $(+)$ \\
\hline & & 188.0 & 25 & \\
\hline Carbendazim & 192.1 & 160.1 & 5 & $(+)$ \\
\hline & & 132.1 & 30 & \\
\hline & & 105.1 & 35 & \\
\hline Clomazone & 240.1 & 200.3 & 1 & $(+)$ \\
\hline Difenoconazole & 406.2 & 251.1 & 25 & $(+)$ \\
\hline & & 338.0 & 15 & \\
\hline Epoxyconazole & 330.1 & 121.2 & 20 & $(+)$ \\
\hline & & 101.2 & 35 & \\
\hline Tebuconazole & 308.2 & 70.0 & 20 & $(+)$ \\
\hline & & 124.9 & 30 & \\
\hline Hexythiazox & 353.0 & 271.0 & 5 & $(+)$ \\
\hline & & 228.1 & 10 & \\
\hline & & 194.1 & 15 & \\
\hline Imidacloprid & 256.0 & 208.9 & 10 & $(+)$ \\
\hline & & 175.1 & 15 & \\
\hline Fipronil & 435.0 & 250.0 & 25 & $(-)$ \\
\hline & & 330.0 & 25 & \\
\hline Chlorpyrifos & 350.0 & 97.0 & 25 & $(+)$ \\
\hline & & 198.0 & 20 & \\
\hline & & 124.9 & 25 & \\
\hline Profenofos & 373.0 & 97.0 & 35 & $(+)$ \\
\hline & & 223.2 & 35 & \\
\hline
\end{tabular}

Table 1 (continued)

\begin{tabular}{lllll}
\hline Compounds & $\begin{array}{l}\text { Precursor ion } \\
(\mathrm{m} / \mathrm{z})\end{array}$ & $\begin{array}{l}\text { Product ion } \\
(\mathrm{m} / \mathrm{z})\end{array}$ & $\begin{array}{l}\text { Collision energy } \\
(\mathrm{eV})\end{array}$ & $\begin{array}{l}\text { ESI } \\
\text { mode }\end{array}$ \\
\hline \multirow{3}{*}{ Malathion } & 331.0 & 305.0 & 10 & $(+)$ \\
& & 127.0 & 1 & 15 \\
\hline
\end{tabular}

2014 was an exceptionally dry year. Three sampling areas in the reservoir were selected. In each area, three sampling points were selected, separated by $100-200 \mathrm{~m}$ and between 50 and $200 \mathrm{~m}$ distant from the margins of the reservoir. A boat was used for sample collection. The coordinates of each sampling point were recorded using a GPS (Datum WGS 84, Table 1 SM).

At each sampling point, the conductivity, $\mathrm{pH}$, temperature, and dissolved oxygen concentration were measured with a Horiba U-5000 probe at depths of $0.1,0.5,1.0$, and $1.5 \mathrm{~m}$, and at the bottom. A handheld sonar (Echotest II, Plastimo) was used to determine the maximum depth. Water transparency was measured with a Secchi disk $(30 \mathrm{~cm}$ diameter).

A plastic hose was used to obtain integrated samples of water for the analysis of nutrients (nitrite, nitrate, ammonium, and total phosphorus), total suspended solids (TSS), and chlorophyll (Chl. $a$ ). Briefly the extreme of a ballasted hose is submersed and water from the entire water column enters into the hose. Once filled, both extremes are closed and the hose is raised up (see Paggi et al., 2001 and references therein). The depth of the water column sampled with the hose depended on the maximum depth at the sampling point $(0.5 \mathrm{~m}$ when the maximum depth was $<5 \mathrm{~m}, 3 \mathrm{~m}$ when the depth was $>5$ but $<10 \mathrm{~m}$ ). The hose was repeatedly launched until obtaining $5 \mathrm{~L}$ of water, which were stored in a plastic bottle and kept inside a cool bag until the return to the laboratory.

For analysis of the emerging and regulated pollutants, $1 \mathrm{~L}$ of water was sampled at $0.5 \mathrm{~m}$ in amber glass bottles that had been previously cleaned using (in order) tap water, detergent, ultrapure water, methanol, and acetone. Finally, bottles were calcinated, at $400{ }^{\circ} \mathrm{C}$ for $4 \mathrm{~h}$ (Montagner et al., 2014a).

All the water samples were stored in the dark in a cooler, until arrival at the laboratory. Once in the laboratory, the samples used for nutrients analysis were frozen until analysis (for $<2$ weeks), while the samples used for the analysis of pesticides, illicit drugs, hormones, and pharmaceuticals were stored in a fridge until solid phase extraction (SPE) was performed on the next day.

\subsection{Analytical methods}

For the analysis of chlorophyll, known volumes of water $(0.5$ to $1 \mathrm{~L}$ depending on the sample) were filtered through glass fiber filters (Whatman GF/C, $47 \mathrm{~mm}$ diameter, 0.6-0.7 $\mu \mathrm{m}$ ). The filters were then frozen and stored in the dark. Posteriorly, the filters were ground in a mortar with $90 \%$ acetone and the extracts were poured into centrifuge tubes and stored overnight in a fridge in the dark. On the following day, the samples were centrifuged at $6000 \mathrm{rpm}$ for $30 \mathrm{~min}$, the supernatant was poured in a spectrophotometer cuvette, and the absorbances at 665 and $750 \mathrm{~nm}$ were measured using a spectrophotometer. The concentration of Chl. $a$ was calculated as described by Lorenzen (1967) and Jeffrey and Humphrey (1975).

The TSS contents were determined in the laboratory. $500 \mathrm{ml}$ of water were filtered through a glass fiber filter (Whatman GF/C, $47 \mathrm{~mm}$ diameter, $0.6-0.7 \mu \mathrm{m}$ ). The filter was dried at $80{ }^{\circ} \mathrm{C}$ to constant weight, and TSS was calculated as the weight difference between the dry filter after filtering and the clean filter.

Colorimetric methods employing a spectrophotometer (B572, Micronal) were used for the analysis of nitrite $\left(\mathrm{NO}_{2}^{-}\right)$and nitrate $\left(\mathrm{NO}_{3}^{-}\right)$(Mackereth et al., 1978), ammonium $\left(\mathrm{NH}_{4}^{+}\right)$(Koroleff, 1976), and total phosphorus (total P) (Valderrama, 1981). 
Concentrations of 31 organic compounds were determined, including pharmaceuticals, illicit drugs, endocrine disrupting compounds (EDCs), and pesticides. Water samples were previously filtered through a $1.2 \mu \mathrm{m}$ glass fiber filter (Schleicher \& Schuell) and were then concentrated by SPE extraction (OASIS HLB cartridge, Waters), using methanol, acetonitrile, and water for cartridge conditioning and elution of the target compounds. The analytical standards and reagents were all reagent grade ( $\geq 98.8 \%$ from Sigma-Aldrich or Supelco). Chemical analysis was performed by liquid chromatography-tandem mass spectrometry (LCMS/MS), using an Agilent 1200 Series LC system coupled to an Agilent 6410 Triple Quad mass spectrometer equipped with an electrospray ionization source (ESI), operated in both negative and positive mode, as described by Montagner et al. (2014a) (Table 1).

The degree of trophic alteration in the system was determined by calculation of the trophic state index (TSI) for each sampling point and season, based on Toledo et al. (1983) and considering the concentrations of P and Chl. $a$.

The values obtained for $\mathrm{pH}$, conductivity, TSS, Chl. $a, \mathrm{NO}_{2}^{-}, \mathrm{NO}_{3}^{-}$, $\mathrm{NH}_{4}^{+}$, and total $\mathrm{P}$ were compared with the Brazilian Environmental Quality Standards (EQS) described in CONAMA Resolution 357 for Class I water bodies (CONAMA, 2005), in order to determine the degree of noncompliance of the reservoir.

\subsection{Risk assessment}

The literature and/or webpage's of official environmental agencies were searched in order to compile a list of published PNEC values for the emerging pollutants analyzed in this study (Table 2). Aquatic organisms of different phylum and end points based on reproduction, mortality and physiological responses were selected. The lowest value found for each compound was chosen to maximize the protective threshold (see bibliography on Table 2 and Table $3 \mathrm{SM}$ ). Risk assessment was performed for each site and season, using calculations based on risk quotients (RQs). RQs essentially constitute an index for quantification of the environmental risk of chemicals, and involve comparison of the environmental concentrations of pollutants with the concentrations that should ensure an absence of adverse effects on target organisms, based on empirical data (Isidori et al., 2005). The RQ of a particular substance was calculated by dividing the maximum environmental concentration (MEC) by the predicted no-effect concentration (PNEC). The highest value found was compared to the lowest PNEC value, for a worst-case scenario evaluation. We consider existence of ecotoxicological risk when RQs $\geq 1$, in this case environmental concentration is above the PNEC value and, therefore, risk of adverse effects is supposed.

The risk for raw water from the reservoir to humans, before entering in the drinking water treatment facilities, was assessed by comparing the water quality criteria available in the literature with the environmental concentrations (Table 3 ). This was only performed for site C, where water was extracted for transfer to a water treatment plant supplying drinking water to 6 million inhabitants of the MRSP. In this case we consider existence of risk when environmental concentration is above the water quality criteria.

\subsection{Statistical analysis}

Data were treated using principal component analysis (PCA) in order to identify possible temporal or spatial patterns among the sampling points. PCA is frequently used in exploratory environmental studies, since it enables complex datasets to be transformed into forms that can be more easily interpreted. Using PCA, patterns of similarity among the sampling points could be identified, reflecting the geographical and temporal distributions of the pollutants.

The physical and chemical data were grouped into two different categories: (a) general indicators of anthropogenic pollution and alteration (parameters providing information on levels of nutrients and other limnological indicators), and (b) EPs and pesticides. For each category, PCA was performed using the data obtained for all the sampling points in both sampling campaigns. One PCA procedure was performed with the data for $\mathrm{pH}$, conductivity, TSS, Chl. $a$, and the concentrations of nitrite, nitrate, ammonium, and total P. These variables were used as general indicators of anthropogenic pollution and alteration (Palma et al., 2014a) and are routinely included in monitoring programs for water quality in reservoirs (ECC, 2000; CETESB, 2015). The other PCA procedure employed the concentrations of the pesticides, illicit drugs, EDCs, and pharmaceuticals; these parameters are not normally included (Petrovic et al., 2011). The purpose of analyzing the data separately was to permit clear detection of possible different behaviors (in time and space) of the groups of parameters.

In the case of the EPs and pesticides, the values obtained for some of the compounds analyzed were below the LOQs, and only those compounds with at least one value for a sampling point above the LOQ were included in the statistical analysis. In this case, values below the LOQ were considered as LOQ/2 (ECC, 2009). Due to the differences in the units and magnitudes of the included variables, the data were transformed using $\log (x+1)$, followed by the scaling of each variable using

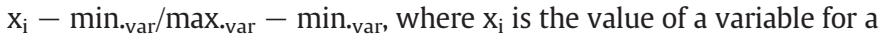
sample, and max.var and min.var are the maximum and minimum values found for the variable (García-Reiriz et al., 2014).

Based on the results obtained in the initial PCA with the EPs and pesticides, two new PCA procedures were then performed, considering the data from the two sampling campaigns separately.

Since the numbers of replicates were not equal in all areas and some variables did not show homogeneity of variances (tested using Levene's test), Welch's ANOVA and the Games-Howell post-hoc test were performed to determine the existence of differences among the areas. In addition, Spearman correlation coefficients were used to assess possible relationships among the common indicators of human impact ( $\mathrm{pH}$, conductivity, TSS, Chl. $a, \mathrm{NO}_{2}^{-}, \mathrm{NO}_{3}^{-}, \mathrm{NH}_{4}^{+}$, and total $\mathrm{P}$ ) and the concentrations of the EPs and pesticides.

The PCA procedures were performed with the PAST 3 statistical package, and SPSS 13.0 was used for the correlation analyses and the ANOVA and post-hoc tests.

\section{Results}

\subsection{Physical and chemical parameters}

\subsubsection{General indicators}

In the first campaign, it was only possible to sample two points in area $\mathrm{C}$, due to climatological constraints. Fig. 2 provides a comparison of the mean values of the different parameters for each area and season. Table 2 SM provides the raw data, with integrated values for the first meter of the water columns.

In the first sampling campaign (Feb. 2014), $\mathrm{pH}$, conductivity, Chl. $a$, total $\mathrm{P}$, and $\mathrm{NO}_{3}^{-}$showed significant differences among the areas $(p<0.05$, Welch's ANOVA test); the post-hoc test revealed significant differences between area $\mathrm{A}$ and the other two areas for $\mathrm{pH}$, conductivity, and Chl. $a(\mathrm{p}<0.05)$, and between areas $\mathrm{A}$ and $\mathrm{C}$ for total $\mathrm{P}$ and $\mathrm{NO}_{3}^{-}$ $(\mathrm{p}<0.05)$. In the second sampling campaign (Oct. 2014), $\mathrm{pH}$, conductivity, TSS, Chl. $a$, and $\mathrm{NO}_{3}^{-}$showed significant differences between the areas ( $p<0.05$, Welch's ANOVA test); the post-hoc test showed significant differences between areas $\mathrm{A}$ and $\mathrm{C}$ for $\mathrm{pH}$; between area $\mathrm{A}$ and the other two areas for conductivity, TSS, and Chl. $a$; and between area $C$ and the other two areas for $\mathrm{NO}_{3}^{-}(\mathrm{p}<0.05)$.

In both seasons, the concentration of total $\mathrm{P}$ exceeded the Brazilian Standards limit value (Resolution 357; CONAMA, 2005). In both periods, the Chl. $a$ values exceeded the Resolution 357 benchmark in areas B and C. The $\mathrm{pH}$ values (from 5.54 to 5.75 ) were below the Resolution 357 benchmark in area $\mathrm{A}$ in the first campaign. In both sampling periods, the conductivity in area A showed low values, compared to the other areas, with values of $48 \pm 1.15$ and $47 \pm 4.16 \mu \mathrm{S} \mathrm{cm}^{-1}$ in the first and second campaigns, respectively (mean values for the 3 sampling 
Table 2

Environmental concentrations, in $\mathrm{ng} \mathrm{L}^{-1}$, of the selected compounds in the Guarapiranga reservoir, type of substance and frequency.

\begin{tabular}{|c|c|c|c|c|c|c|c|c|c|c|c|c|c|c|c|c|c|c|c|c|c|c|c|c|c|}
\hline \multirow[b]{2}{*}{ Compound } & \multirow[b]{2}{*}{ CAS number } & \multirow[b]{2}{*}{ Type of substance and chemical group } & \multicolumn{10}{|c|}{$\begin{array}{l}\text { February } 2014 \\
\left(\mathrm{ng} \mathrm{L}^{-1}\right)\end{array}$} & \multicolumn{10}{|c|}{$\begin{array}{l}\text { October } 2014 \\
\left(\mathrm{ng} \mathrm{L}^{-1}\right)\end{array}$} & \multicolumn{3}{|c|}{$\begin{array}{l}\text { Frequency } \\
\text { (positive/total) }\end{array}$} \\
\hline & & & LOQ & A1 & A2 & A3 & B1 & B2 & B3 & $\mathrm{C} 1$ & $\mathrm{C} 2$ & $\mathrm{C} 3$ & LOQ & A1 & $\mathrm{A} 2$ & A3 & B1 & B2 & B3 & $\mathrm{C} 1$ & $\mathrm{C} 2$ & C3 & A & B & $\mathrm{C}$ \\
\hline Caffeine & [58-08-2] & Stimulant alkaloid & 4.0 & $\mathrm{MD}$ & 44 & 53 & 22 & 17 & 130 & 146 & 53 & $\mathrm{MD}$ & 5.8 & 362 & 300 & 336 & 4726 & 1870 & 1290 & 244 & 273 & 477 & $5 / 5$ & $6 / 6$ & $5 / 5$ \\
\hline Diclofenac & {$[15,307-86-5]$} & $\begin{array}{l}\text { Pharmaceutical, non-steroidal anti-inflammatory } \\
\text { drug }\end{array}$ & 14 & MD & $<14$ & & & & & & & MD & 14 & $<14$ & & & & & & & & & $0 / 5$ & $0 / 6$ & $0 / 5$ \\
\hline Cocaine & [50-36-2] & Illicit drug & 2.5 & MD & 3 & 4 & 4 & 7 & 12 & 3 & 3 & MD & 65 & $<65$ & & & & & & & & & $2 / 5$ & $3 / 6$ & $2 / 5$ \\
\hline Benzoylecgonine & [519-09-5] & Illicit drug metabolite (cocaine) & 4.3 & MD & 15 & 17 & 53 & 108 & 179 & 18 & 15 & MD & 1.5 & 10 & 9.2 & 9.2 & 121 & 55 & 37 & 4.3 & 4.4 & 3.2 & $5 / 5$ & $6 / 6$ & $5 / 5$ \\
\hline $17 \alpha$-ethinylestradiol & [57-63-6] & Pharmaceutical, xenoestrogen & 40 & MD & $<40$ & & & & & & & MD & 58 & $<58$ & & & & & & & & & $0 / 5$ & $0 / 6$ & $0 / 5$ \\
\hline 17ß-estradiol & [50-28-2] & Pharmaceutical/natural hormone, estrogen & 36 & MD & $<36$ & & & & & & & MD & 29 & $<29$ & & & & & & & & & $0 / 5$ & $0 / 6$ & $0 / 5$ \\
\hline Estriol & [50-27-1] & Metabolie & 37 & MD & $<37$ & & & & & & & $\mathrm{MD}$ & 46 & $<46$ & & & & & & & & & $0 / 5$ & $0 / 6$ & $0 / 5$ \\
\hline Estrone & [53-16-7] & Metabolie & 13 & MD & $<13$ & & & & & & & $\mathrm{MD}$ & 11 & $<11$ & & & & & & & & & $0 / 5$ & $0 / 6$ & $0 / 5$ \\
\hline Progesterone & {$[57-83-0]$} & Pharmaceutical/natural hormone, progestrogen & 1 & MD & $<1$ & & & & & & & $\mathrm{MD}$ & 4.8 & $<4.8$ & & & & & & & & & $0 / 5$ & $0 / 6$ & $0 / 5$ \\
\hline Testosterone & [58-22-0] & Pharmaceutical/natural hormone, androgen & 0.9 & MD & $<0.9$ & & & & & & & MD & 2.1 & $<2.1$ & & & & & & & & & $0 / 5$ & $0 / 6$ & $0 / 5$ \\
\hline Triclosan & [3380-34-5] & Antibacterial and antifungal agent & 22 & MD & $<22$ & & & & & & & MD & 21 & $<21$ & & & & & & & & & $0 / 5$ & $0 / 6$ & $0 / 5$ \\
\hline Bisphenol A & {$[80-05-7]$} & Plasticizer & 33 & MD & 113 & 147 & 174 & 345 & 156 & 299 & 119 & $\mathrm{MD}$ & 10 & $<10$ & 16 & $<10$ & 30 & 12 & 10 & 20 & 16 & 17 & $3 / 5$ & $6 / 6$ & $5 / 5$ \\
\hline Ametryn & [834-12-8] & Triazine herbicide & 0.5 & MD & 0.9 & 1.0 & 1.1 & 1.1 & $<0.5$ & 1.0 & 0.9 & MD & 1 & $<1$ & & & & & & & & & $2 / 5$ & $2 / 6$ & $2 / 5$ \\
\hline Atrazine & [1912-24-9] & Triazine herbicide & 0.9 & MD & 1.0 & 1.0 & 1.9 & 2.4 & 1.0 & 1.3 & 1.1 & MD & 1.1 & $<1.1$ & & & & & & & & & $2 / 5$ & $3 / 6$ & $2 / 5$ \\
\hline Simazine & [122-34-9] & Triazine herbicide & 0.6 & MD & $<0.6$ & & & & & & & MD & 1.3 & $<1.3$ & & & & & & & & & $0 / 5$ & $0 / 6$ & $0 / 5$ \\
\hline Azoxystrobin & [131860-33-8] & Strobilurin fungicide & 0.5 & MD & $<0.5$ & 1.1 & $<0.5$ & $<0.5$ & $<0.5$ & 1.1 & $<0.5$ & MD & 1.2 & $<1.2$ & & & & & & & & & $1 / 5$ & $0 / 6$ & $1 / 5$ \\
\hline Picoxystrobin & [117428-22-5] & Uracil herbicide & 0.4 & MD & $<0.4$ & & & & & & & MD & 1.1 & $<1.1$ & & & & & & & & & $0 / 5$ & $0 / 6$ & $0 / 5$ \\
\hline Pyraclostrobin & [175013-18-0] & Strobilurin type-methoxyacrylate fungicide & 0.6 & MD & $<0.6$ & & & & & & & MD & 1.8 & $<1.8$ & & & & & & & & & $0 / 5$ & $0 / 6$ & $0 / 5$ \\
\hline Trifloxystrobin & [141517-21-7] & Strobilurin fungicide & 1.1 & MD & $<1.1$ & & & & & & & MD & 3.2 & $<3.2$ & & & & & & & & & $0 / 5$ & $0 / 6$ & $0 / 5$ \\
\hline Bromacil & [314-40-9] & Uracil herbicide & 0.6 & MD & $<0.6$ & & & & & & & MD & 4.0 & $<4.0$ & & & & & & & & & $0 / 5$ & $0 / 6$ & $0 / 5$ \\
\hline Carbendazim & {$[10605-21-7]$} & Benzimidazole fungicide & 1.5 & MD & 12 & 19 & 101 & 87 & 9.0 & 67 & 16 & MD & 1.2 & 16 & 15 & 15 & 160 & 162 & 124 & 33 & 34 & 20 & $5 / 5$ & $6 / 6$ & $5 / 5$ \\
\hline Clomazone & [81777-89-1] & Isoxazolidinone herbicide & 1.0 & MD & $<1.0$ & & & & & & & MD & 0.8 & $<0.8$ & & & & & & & & & $0 / 5$ & $0 / 6$ & $0 / 6$ \\
\hline Difenoconazole & [119446-68-3] & Triazole fungicide & 0.6 & MD & $<0.6$ & & & & & & & MD & 0.9 & $<0.9$ & & & & & & & & & $0 / 5$ & $0 / 6$ & $0 / 5$ \\
\hline Epoxyconazole & {$[133855-98-8]$} & Triazole fungicide & 0.6 & MD & 0.7 & 0.7 & 0.7 & 0.8 & $<0.6$ & 0.8 & $<0.6$ & MD & 1.4 & $\begin{array}{l}< \\
1.4\end{array}$ & $\begin{array}{l}< \\
1.4\end{array}$ & $\begin{array}{l}< \\
1.4\end{array}$ & $<1.4$ & $<1.4$ & $<1.4$ & $\begin{array}{l}< \\
1.4\end{array}$ & $\begin{array}{l}< \\
1.4\end{array}$ & $\begin{array}{l}< \\
1.4\end{array}$ & $2 / 5$ & $2 / 6$ & $1 / 5$ \\
\hline Tebuconazole & [107534-96-3] & Triazole fungicide & 0.9 & MD & 1.1 & 1.1 & 1.2 & 1.3 & 0.9 & 1.3 & 1.0 & MD & 1 & $<1$ & & & & & & & & & $2 / 5$ & $3 / 6$ & $2 / 5$ \\
\hline Hexythiazox & [78587-05-0] & Carboxamide acaricide & 1.8 & MD & $<1.8$ & & & & & & & MD & NA & & & & & & & & & & $0 / 5$ & $0 / 6$ & $0 / 5$ \\
\hline Imidacloprid & [138261-41-3] & Neonicotinoid insecticide, veterinary drug & 0.7 & MD & 1.3 & 1.6 & $<0.7$ & $<0.7$ & $<0.7$ & $<0.7$ & $<0.7$ & MD & 2.1 & 2.6 & 2.4 & 3.0 & $<2.1$ & $<2.1$ & $<2.1$ & $\begin{array}{l}< \\
2.1\end{array}$ & $\begin{array}{l}< \\
2.1\end{array}$ & $\begin{array}{l}< \\
2.1\end{array}$ & $5 / 5$ & $0 / 6$ & $0 / 5$ \\
\hline Fipronil & [120068-37-3] & Phenylpyrazole insecticide, veterinary drug & 6 & MD & $<6$ & & & & & & & MD & 1.1 & 1.3 & 1.3 & 1.3 & 2.0 & 1.6 & 1.5 & 1.4 & 1.4 & 1.5 & $3 / 5$ & $3 / 6$ & $3 / 5$ \\
\hline Chlorpyrifos & [2921-88-2] & Organophospate insecticide & 2.3 & MD & $<2.3$ & & & & & & & MD & & NA & & & & & & & & & $0 / 5$ & $0 / 6$ & $0 / 5$ \\
\hline Profenofos & {$[41,198-08-7]$} & Organophospate insecticide & 15.1 & MD & $<15.1$ & & & & & & & MD & & NA & & & & & & & & & $0 / 5$ & $0 / 6$ & $0 / 5$ \\
\hline Malathion & [121-75-5] & Organophospate insecticide, veterinary drug & 1.1 & MD & $<1.1$ & & & & & & & MD & & NA & & & & & & & & & $0 / 5$ & $0 / 6$ & $0 / 5$ \\
\hline
\end{tabular}

Legend: (-) value not found in the literature; (MD) missing datum; (LOQ) limit of quantification; (NA) not analyzed. 
Table 3

Drinking Water Criteria (DWC) and concentrations and frequency of detection for EPs and pesticides in area C for both sampling campaigns.

\begin{tabular}{|c|c|c|c|c|c|c|c|c|c|c|c|}
\hline \multirow[b]{2}{*}{ Compound } & \multirow[b]{2}{*}{ CAS number } & \multirow{2}{*}{$\begin{array}{l}\text { DWC } \\
\left(\text { ng L L }^{-1}\right)\end{array}$} & \multicolumn{4}{|c|}{$\begin{array}{l}\text { February } 2014 \\
\left(\mathrm{ng} \mathrm{L}^{-1}\right)\end{array}$} & \multicolumn{4}{|c|}{$\begin{array}{l}\text { October } 2014 \\
\left(\mathrm{ng} \mathrm{L}^{-1}\right)\end{array}$} & \multirow{2}{*}{$\begin{array}{l}\text { Frequency } \\
\text { positive/total }\end{array}$} \\
\hline & & & LOQ & $\mathrm{C} 1$ & $\mathrm{C} 2$ & C3 & LOQ & $\mathrm{C} 1$ & $\mathrm{C} 2$ & $\mathrm{C} 3$ & \\
\hline Caffeine & {$[58-08-2]$} & - & 4.0 & 146 & 53 & MD & 5.8 & 244 & 273 & 477 & $5 / 5$ \\
\hline Diclofenac & [15307-86-5] & - & 14 & $<14$ & $<14$ & MD & 14 & $<14$ & $<14$ & $<14$ & $0 / 5$ \\
\hline Cocaine & {$[50-36-2]$} & - & 2.5 & 3 & 3 & MD & 65 & $<65$ & $<65$ & $<65$ & $2 / 5$ \\
\hline Benzoylecgonine & [519-09-5] & - & 4.3 & 18 & 15 & MD & 1.5 & 4.3 & 4.4 & 3.2 & $5 / 5$ \\
\hline $17 \alpha$-ethinylestradiol & {$[57-63-6]$} & - & 40 & $<40$ & $<40$ & MD & 58 & $<58$ & $<58$ & $<58$ & $0 / 5$ \\
\hline $17 \beta$-estradiol & [50-28-2] & $3.8^{\mathrm{a}}$ & 36 & $<36$ & $<36$ & MD & 29 & $<29$ & $<29$ & $<29$ & $0 / 5$ \\
\hline Estriol & [50-27-1] & - & 37 & $<37$ & $<37$ & MD & 46 & $<46$ & $<46$ & $<46$ & $0 / 5$ \\
\hline Estrone & [53-16-7] & - & 13 & $<13$ & $<13$ & $\mathrm{MD}$ & 11 & $<11$ & $<11$ & $<<11$ & $0 / 5$ \\
\hline Progesterone & [57-83-0] & $333^{a}$ & 1 & $<1$ & $<1$ & MD & 4.8 & $<4.8$ & $<4.8$ & $<4.8$ & $0 / 5$ \\
\hline Testosterone & [58-22-0] & $11^{\mathrm{a}}$ & 0.9 & $<0.9$ & $<0.9$ & MD & 2.1 & $<2.1$ & $<2.1$ & $<2.1$ & $0 / 5$ \\
\hline Triclosan & [3380-34-5] & $2,000,000^{\mathrm{b}}$ & 22 & $<22$ & $<22$ & MD & 21 & $<21$ & $<21$ & $<21$ & $0 / 5$ \\
\hline Bisphenol A & [80-05-7] & - & 33 & 299 & 199 & MD & 10 & 20 & 16 & 17 & $5 / 5$ \\
\hline Ametryn & [834-12-8] & $400,000^{\mathrm{b}}$ & 0.5 & 1.0 & 0.9 & MD & 1 & $<1$ & $<1$ & $<1$ & $2 / 5$ \\
\hline Atrazine & [1912-24-9] & $2000^{c}$ & 0.9 & 1.3 & 1.1 & MD & 1.1 & $<1.1$ & $<1.1$ & $<1.1$ & $2 / 5$ \\
\hline Simazine & [122-34-9] & $2000^{d}$ & 0.6 & $<0.6$ & $<0.6$ & MD & 1.3 & $<1.3$ & $<1.3$ & $<1.3$ & $0 / 5$ \\
\hline Azoxystrobin & [131860-33-8] & $100,000^{\mathrm{b}}$ & 0.5 & 1.1 & $<0.5$ & MD & 1.2 & $<1.2$ & $<1.2$ & $<1.2$ & $1 / 5$ \\
\hline Picoxystrobin & [117428-22-5] & $260,000^{\mathrm{e}}$ & 0.4 & $<0.4$ & $<0.4$ & MD & 1.1 & $<1.1$ & $<1.1$ & $<1.1$ & $0 / 5$ \\
\hline Pyraclostrobin & [175013-18-0] & $240,000^{\mathrm{e}}$ & 0.6 & $<0.6$ & $<0.6$ & MD & 1.8 & $<1.8$ & $<1.8$ & $<1.8$ & $0 / 5$ \\
\hline Trifloxystrobin & [141517-21-7] & $180,000^{\mathrm{e}}$ & 1.1 & $<1.1$ & $<1.1$ & MD & 3.2 & $<3.2$ & $<3.2$ & $<3.2$ & $0 / 5$ \\
\hline Bromacil & [314-40-9] & $400,000^{f}$ & 0.6 & $<0.6$ & $<0.6$ & MD & 4.0 & $<4.0$ & $<4.0$ & $<4.0$ & $0 / 5$ \\
\hline Carbendazim & [10605-21-7] & $120,000^{c}$ & 1.5 & 67 & 16 & MD & 1.2 & 33 & 34 & 20 & $5 / 5$ \\
\hline Clomazone & [81777-89-1] & $200,000^{\mathrm{b}}$ & 1.0 & $<1.0$ & $<1.0$ & MD & 0.8 & $<0.8$ & $<0.8$ & $<0.8$ & $0 / 5$ \\
\hline Difenoconazole & [119446-68-3] & $3,600,000^{\mathrm{e}}$ & 0.6 & $<0.6$ & $<0.6$ & MD & 0.9 & $<0.9$ & $<0.9$ & $<0.9$ & $0 / 5$ \\
\hline Epoxyconazole & [133855-98-8] & $18,000^{\mathrm{e}}$ & 0.6 & 0.8 & $<0.6$ & MD & 1.4 & $<1.4$ & $<1.4$ & $<1.4$ & $1 / 5$ \\
\hline Tebuconazole & [107534-96-3] & $180,000^{c}$ & 0.9 & 1.3 & 1.0 & MD & 1 & $<1$ & $<1$ & $<1$ & $2 / 5$ \\
\hline Hexythiazox & [78587-05-0] & - & 1.8 & $<1.8$ & $<1.8$ & MD & NA & & & & $0 / 5$ \\
\hline Imidacloprid & [138261-41-3] & $300,000^{\mathrm{e}}$ & 0.7 & $<0.7$ & $<0.7$ & MD & 2.1 & $<2.1$ & $<2.1$ & $<2.1$ & $5 / 5$ \\
\hline Fipronil & [120068-37-3] & $1000^{\mathrm{b}}$ & 6 & $<6$ & $<6$ & MD & 1.1 & 1.4 & 1.4 & 1.5 & $3 / 5$ \\
\hline Chlorpyrifos & [2921-88-2] & - & 2.3 & $<2.3$ & $<2.3$ & MD & NA & & & & $0 / 5$ \\
\hline Profenofos & [41198-08-7] & - & 15.1 & $<15.1$ & $<15.1$ & MD & NA & & & & $0 / 5$ \\
\hline Malathion & {$[121-75-5]$} & $190,000^{\mathrm{g}}$ & 1.1 & $<1.1$ & $<1.1$ & MD & NA & & & & $0 / 5$ \\
\hline
\end{tabular}

Legend: (-) value not found in the literature; (MD) missing datum; (LOQ) limit of quantification; (DWC) drinking water criteria; (NA) not analyzed.

Source of DWC values:

a Brand et al. (2013).

b de A. Umbuzeiro (2012).

c Brasilian Ministry of Health (2011).

d WHO (2011).

e Barbosa et al. (2015).

f New Zealand Ministry of Health, 2008.

g Health Canada, 2014.

points). In the second campaign, area A showed the lowest mean TSS value $\left(2.46 \pm 0.7 \mathrm{mg} \mathrm{L}^{-1}\right)$ and area $B$ the highest $\left(9.6 \pm 1.6 \mathrm{mg} \mathrm{L}^{-1}\right)$. Area $\mathrm{B}$ showed the highest total $\mathrm{P}$ and $\mathrm{NH}_{4}^{+}$concentrations in both seasons, with values of 165.70 and $628.93 \mu \mathrm{g} \mathrm{L}^{-1}$ in the first and second campaigns, respectively, in the case of total $\mathrm{P}$, and values of 650.39 and $2330.43 \mu \mathrm{g} \mathrm{L}^{-1}$ in the first and second campaigns, respectively, in the case of $\mathrm{NH}_{4}^{+}$, although the differences between the areas were not significant. The lowest concentrations of $\mathrm{NO}_{2}^{-}$and $\mathrm{NO}_{3}^{-}$were found in area $\mathrm{A}$, in both seasons, while the highest levels of $\mathrm{NO}_{3}^{-}$were found in area $C$, with mean values of $615.27 \pm 4.94$ and $1129.74 \pm 234.44 \mu \mathrm{g}$ $\mathrm{L}^{-1}$ in the first and second sampling campaigns, respectively. In both seasons, the mean concentration of Chl. $a$ in area $\mathrm{A}\left(6.75 \pm 1.5 \mu \mathrm{g} \mathrm{L} \mathrm{L}^{-1}\right.$ in the first campaign and $5.06 \pm 1.12 \mu \mathrm{L} \mathrm{L}^{-1}$ in the second campaign) was one order of magnitude lower than in areas B and C. Areas B and C showed similar concentrations of Chl. $a$ in the rainy season $(27.5 \pm$ 5.71 and $24.67 \pm 0.05 \mu \mathrm{g} \mathrm{L}{ }^{-1}$, respectively), while in the dry season the concentration of Chl. $a$ in area B approximately doubled (65.21 \pm $\left.11.54 \mu \mathrm{g} \mathrm{L}^{-1}\right)$.

Oxygen concentration was not included in the analysis. Values obtained during the second sampling campaign were not reliable, probably due to probe failure for this parameter during the fieldwork.

The TSI at the sampling points ranged from mesoeutrophic to hypereutrophic, according to the classification described by Toledo et al. (1983). The points situated in area A were mesoeutrophic in both periods, while the points in area $B$ were classified as eutrophic in the first sampling campaign (Feb. 2014, rainy season) and hypereutrophic in the second campaign (Oct. 2014, dry season). The points in area C were always classified as eutrophic. These data suggested the existence of a nutrient enrichment gradient in the reservoir, with area B being a hotspot.

\subsubsection{Emerging pollutants and pesticides}

In the first campaign (Feb. 2014, rainy season), one sample from area A was lost and it was not possible to analyze the concentrations of the pesticides and EPs. A total of $31 \mathrm{EPs}$ and pesticides were detected in the Guarapiranga Reservoir in the first sampling campaign (Feb. 2014, rainy season), and 27 in the second (Oct. 2014, dry season, when the pesticides hexythiazox, chlorpyrifos, profenofos, and malathion were not analyzed). The concentrations of the compounds ranged from 0.6 $\mathrm{ng} \mathrm{L^{-1 }}$ to $4700 \mathrm{ng} \mathrm{L}^{-1}$ (Table 2), depending on the period and location. Cocaine, atrazine, ametryn, azoxystrobin, epoxiconazole, and tebuconazole were only quantified in the rainy season. Diclofenac and fipronil were only quantified in the dry season. In the case of diclofenac, only one point in area B showed a concentration above the LOQ. Bisphenol A (BPA), caffeine, the cocaine metabolite benzoylecgonine, and the pesticides carbendazim and imidacloprid were all quantified in both periods. In the case of imidacloprid, the concentrations were only above the LOQ in both periods in area A. Consequently, more compounds were quantified in the first campaign (11) than in the second campaign (7).

The EPs showed no significant differences between the sampling points in the first campaign, but significant differences were detected in the second period for bencoylecgonine, carbendazim, and 

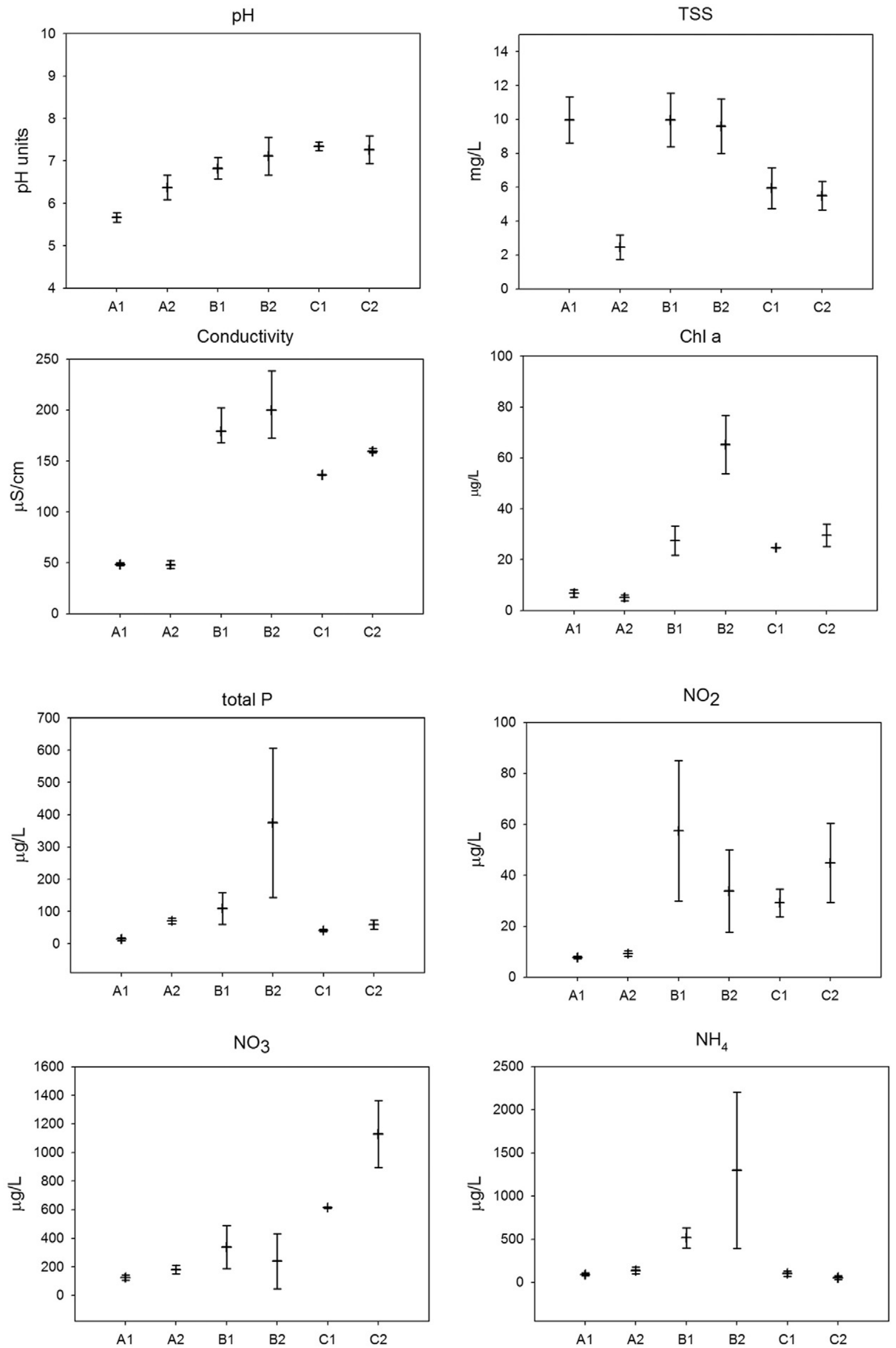

Fig. 2. Means and standard deviations for the common water quality parameters, according to location and sampling season. 
imidacloprid ( $p<0.05$, Welch's ANOVA). The post-hoc test discriminated between areas $A$ and $C$ for bencoylecgonine, between area $B$ and the other two areas for carbendazim, and between area $A$ and the other two areas for imidacloprid $(p<0.05)$. In the case of imidacloprid, Levene's test did not confirm homogeneity of variances and it was not possible to perform the Welch's ANOVA procedure because at least one group had zero variance.

Depending on season and area, the compounds with the highest concentrations were (in order) caffeine, BPA, benzoylecgonine, and carbendazim. Caffeine was the compound with the highest concentrations, especially in the dry season (concentrations range from 244 to $4700 \mathrm{ng} \mathrm{L}^{-1}$ ) and in area $\mathrm{B}$ (4700 $\mathrm{ng} \mathrm{L}^{-1}$ at one point). In the case of $\mathrm{BPA}$, the concentrations in all areas in the first period (rainy season), with values from 113 to $345 \mathrm{ng} \mathrm{L}^{-1}$, were one order of magnitude higher than in the dry season. In both seasons, benzoylecgonine showed higher concentrations in area $\mathrm{B}$, compared to the other areas (mean values of $113.33 \pm 63.2 \mathrm{ng} \mathrm{L}^{-1}$ in the first campaign and $71 \pm 44.22$ $\mathrm{ng} \mathrm{\textrm {L } ^ { - 1 }}$ in the second campaign), although the differences were not significant. Concentrations of the fungicide carbendazim were significantly higher in area B in the dry season in comparison with the other areas (mean values of $65.66 \pm 49.57 \mathrm{ng} \mathrm{L}^{-1}$ in the first campaign and $148 \pm 21.38 \mathrm{ng} \mathrm{L}^{-1}$ in the second campaign).

\subsection{Principal component analysis and correlations}

The PCA results obtained using the general indicators of anthropogenic pollution and alteration are shown in Fig. 3. The first two components explained $83.52 \%$ of the total variance. The analyses suggested a gradient of pollution from area $\mathrm{A}$ to area $\mathrm{C}$, without any seasonal trends. PC1 (57.57\%) discriminated between points in area $A$ and points in areas $B$ and C. Areas B and C showed high values for nutrients, Chl. $a$, and conductivity. Area $\mathrm{C}$ was associated with increased $\mathrm{pH}$ and high concentrations of nitrites and nitrates, while area B showed high values for $\mathrm{P}, \mathrm{Chl}$. $a$, TSS, conductivity, and ammonium.
Fig. 4 shows the PCA results obtained using the data for the EPs and pesticides. In the first instance, the data for the two sampling periods were analyzed together. The two first axes explained $84.19 \%$ of the variance. PC1 (69.9\%) separated points of the first sampling campaign from those of the second period, indicating the existence of a seasonal trend. PC2 (14.29\%) separated the points of area B from the rest of the points, suggesting a possible pollution gradient and highlighting area $\mathrm{B}$ as a possible hotspot. Given these results, PCA was then performed using the EP and pesticide data for the first and second sampling campaigns separately.

Using the emerging pollutant and pesticide data from the first campaign, in the rainy season, PC1 and PC2 explained $71.31 \%$ of the variance (Fig. 5). The distribution of the sampling points in the $2 \mathrm{D}$ representation showed no clear spatial trends. Although PC2 seemed to discriminate the points situated in area $B$ from the remaining points, points from areas $A$ and $C$ were mixed. The points in area $B$ were those most affected by high concentrations of illicit drugs, pesticides, and endocrine disrupters, while the other locations were mainly influenced by the presence of pesticides.

In the PCA using the data for the emerging pollutants and pesticides from the second campaign in the dry season (Fig. 6), PC1 and PC2 explained $87.91 \%$ of the variance. In this case, the sampling points were grouped according to the different areas in the 2D representation, suggesting the existence of spatial trends in the pollutant concentrations. Area A was affected by the presence of the insecticide imidacloprid. Area B was influenced by higher concentrations of a range of pollutants (pesticides, pharmaceuticals, illicit drugs, and endocrine disrupters). Finally, area $\mathrm{C}$ was affected by the presence of BPA.

Significant correlations were obtained between the EPs and the common indicators of human pollution (Table 4). The compound imidacloprid was most highly (negatively) correlated with $\mathrm{pH}$, conductivity, Chl. $a$, total P, nitrite, and nitrate, followed by benzoylecgonine, which was positively correlated with conductivity, total $\mathrm{P}$, and ammonium.

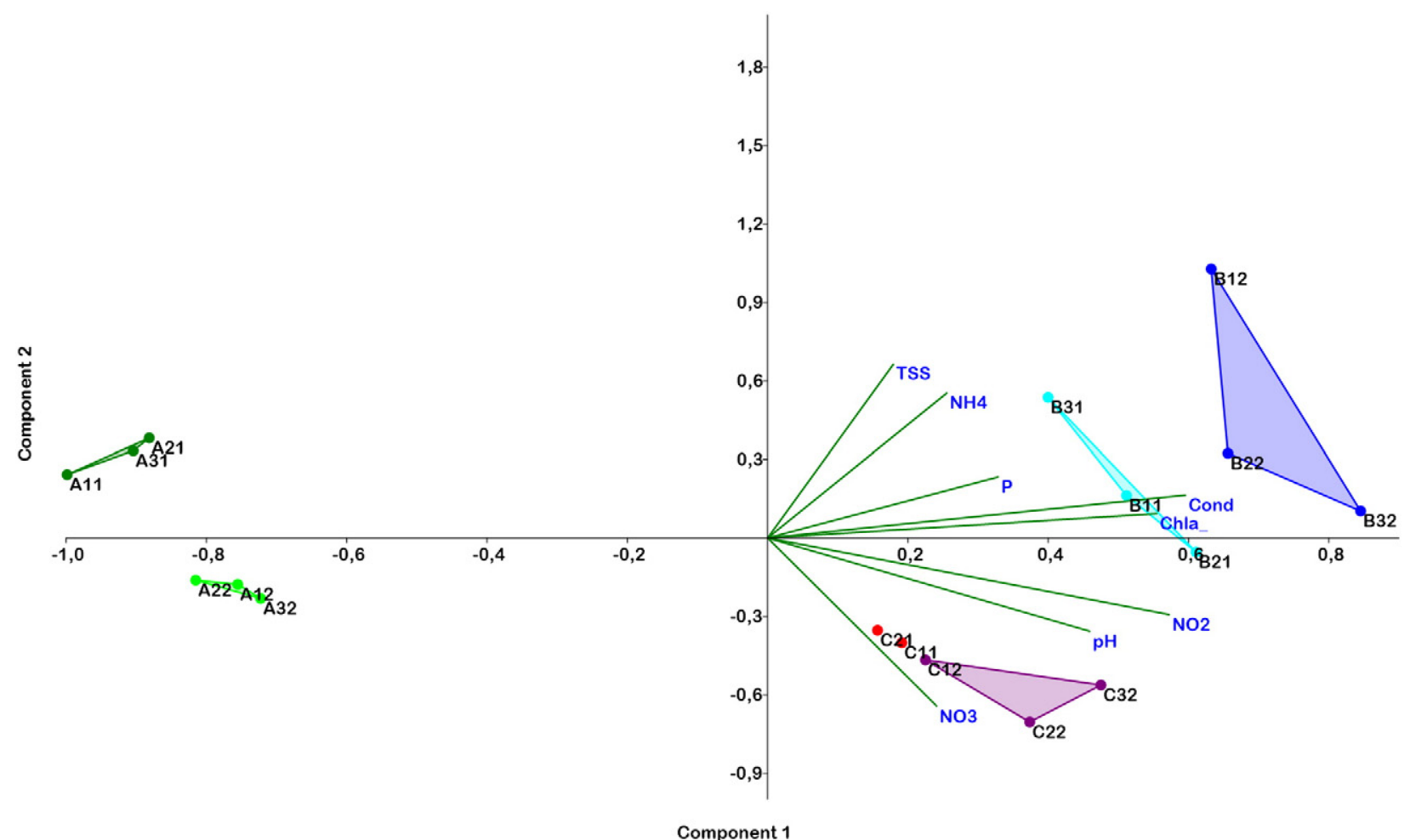

Fig. 3. PCA using data for the common water quality parameters. 
ำ

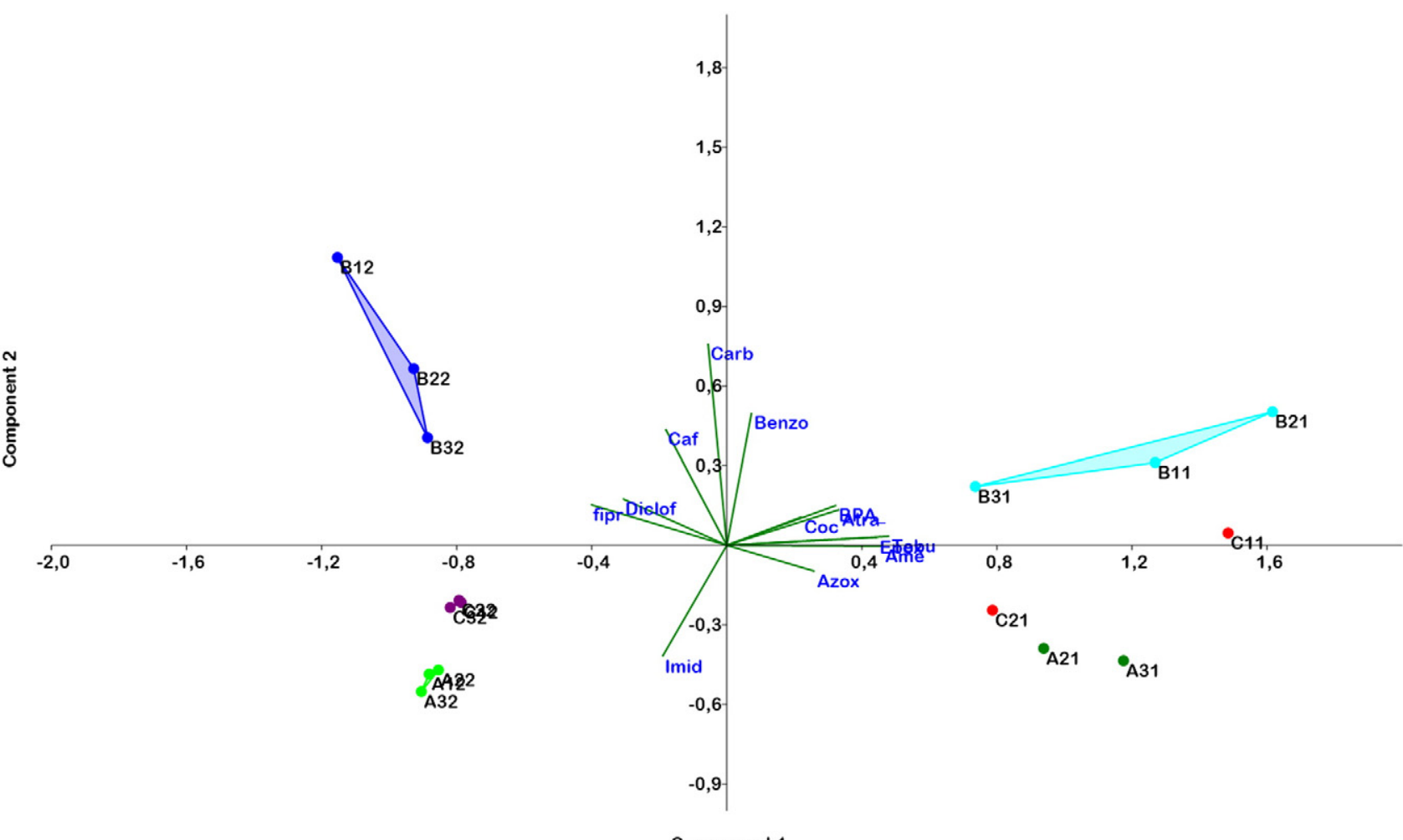

Component 1

Fig. 4. PCA using data for the EPs and pesticides from both sampling campaigns.

\subsection{Risk assessment}

Fig. 7 presents the ranges of concentrations obtained for the most critical compounds, together with the corresponding PNECs reported in the literature. BPA showed risk in all three areas in both sampling periods. Carbendazim and imidacloprid showed risk after the dry season in areas A and B, respectively. Caffeine showed values very close to risk in area $B$ after the dry season. For some hormones (17- $\alpha$ -

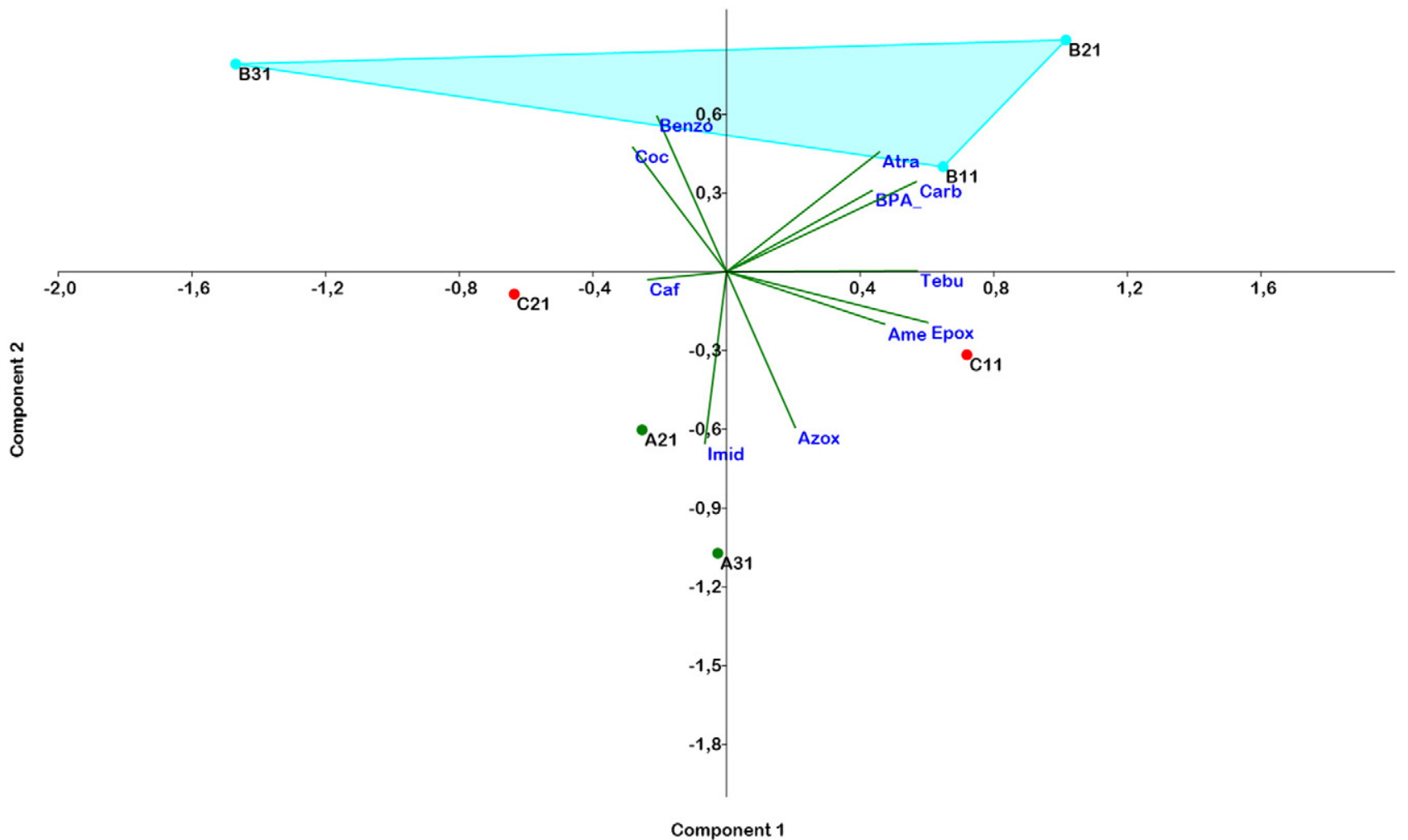

Fig. 5. PCA using data for the EPs and pesticides from the first sampling campaign (rainy season). 


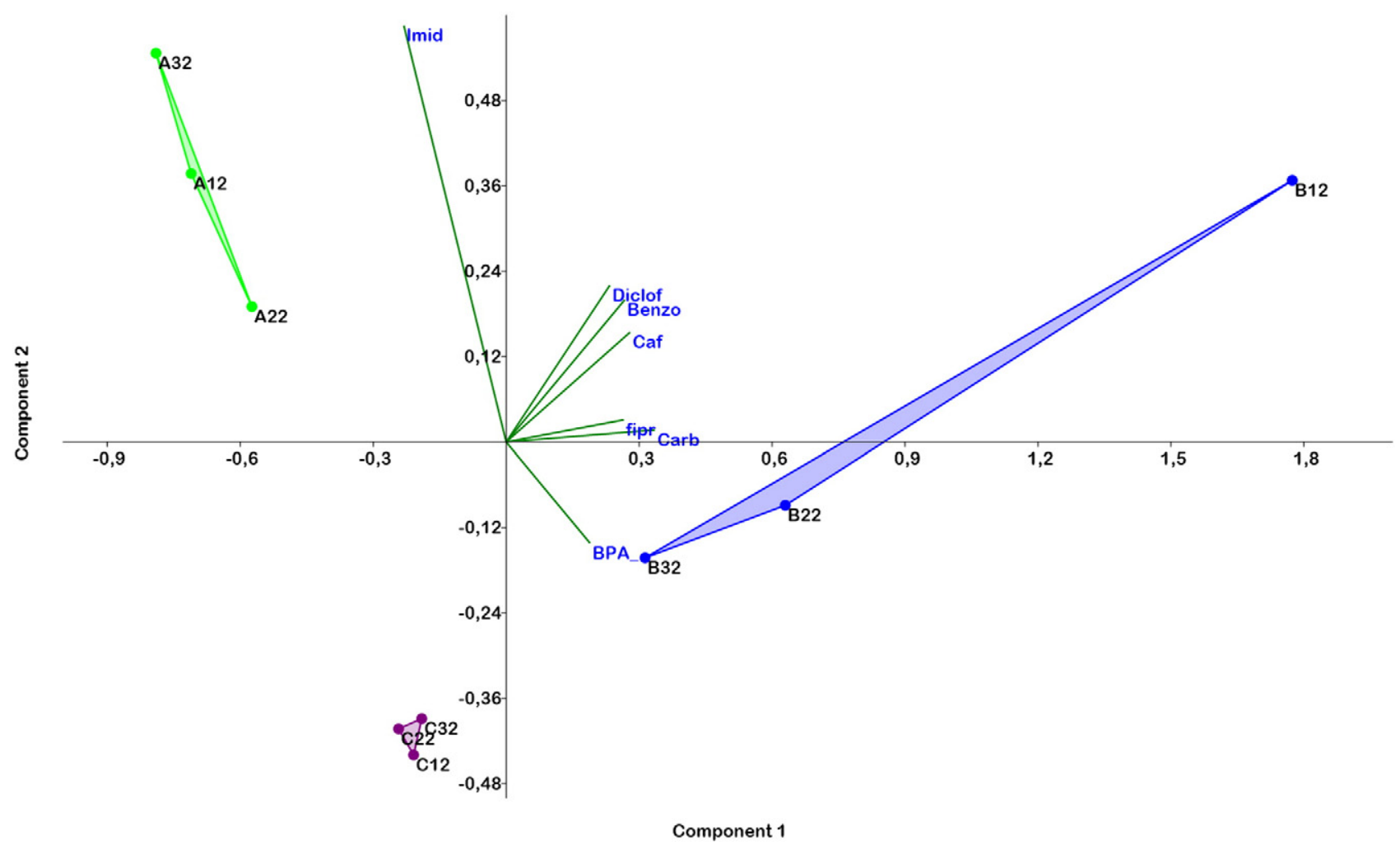

Fig. 6. PCA using data for the EPs and pesticides from the second sampling campaign (dry season).

ethinylestradiol, 17- $\beta$-estradiol, and estrone), risk assessment was not possible because the LOQs of the applied analytical methods were higher than the lowest PNEC. No risks were observed for the other EPs analyzed in this study.

Published drinking water criteria were found for 3 of the 6 hormones, triclosan, and 16 of the 19 pesticides. No risks to human health were observed in the raw water from the reservoir for the compounds analyzed in this study (Table 3 ).

\section{Discussion}

4.1. General indicators, EPs, and pesticides: spatial distributions and relationships

Our exploratory study demonstrated the presence of pesticides and EPs in the reservoir. High levels of nutrients and Chl. $a$ in the period studied were found. The nutrients and TSI showed gradients in the reservoir, with clearly defined spatial distributions. Such behavior was only obvious for the pesticides and EPs in the dry season. The pesticides and EPs therefore exhibited seasonal behavior in the period studied, with their concentrations and distributions varying according to the sampling period.

Some of the municipalities and neighborhoods within the Guarapiranga catchment have poor wastewater collection and treatment and $<50 \%$ of the wastewater produced in the catchment is collected and treated, (CETESB, 2015; SEADE, 2015), resulting in sewage reaching the rivers and other water bodies that drain into the Guarapiranga. For this reason, levels of total P and Chl. $a$ are high and the reservoir has been classified as eutrophic since 1960, although it can now be considered hypereutrophic (Beyruth, 2000; CETESB, 2014), as supported by the values obtained in our study for Chl. $a$, total P, and TSI.

The common water quality parameters showed a general pattern that suggested the existence of different areas as a function of the level of impact. The PCA using these indicators (Fig. 3) clearly distinguished the sampling points in the specific areas defined previously (A, B, and C), for both sampling campaigns. On the other hand, as can be seen in Fig. 2, some parameters showed high variability within a specific region, indicative of spatial heterogeneity, despite the fact that the sampling points were relatively close to each other (100-200 m).

Table 4

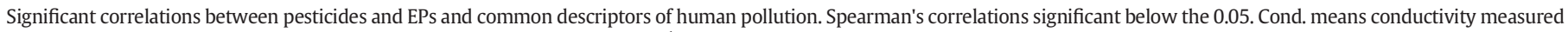

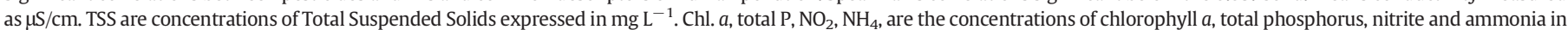
$\mu \mathrm{g} \mathrm{L}-1$.

\begin{tabular}{|c|c|c|c|c|c|c|c|c|}
\hline & $\mathrm{T}$ & $\mathrm{pH}$ & Cond & TSS & Chl. $a$ & Total P & $\mathrm{NO}_{2}$ & $\mathrm{NH}_{4}$ \\
\hline BPA & 0.511 & & & 0.527 & & & & \\
\hline Cocaine & & & & & & 0.767 & & \\
\hline Benzoylecgonine & 0.709 & & 0.609 & & & 0.562 & & 0.823 \\
\hline Caffeine & & & & & & 0.502 & & \\
\hline Carbendazim & & & 0.598 & & 0.825 & 0.511 & 0.599 & \\
\hline Imidacloprid & -0.614 & -0.545 & -0.626 & & & & -0.667 & \\
\hline Atrazine & & & & & 0.927 & & 0.889 & \\
\hline Fipronil & & & 0.975 & 0.949 & 0.838 & & & \\
\hline
\end{tabular}




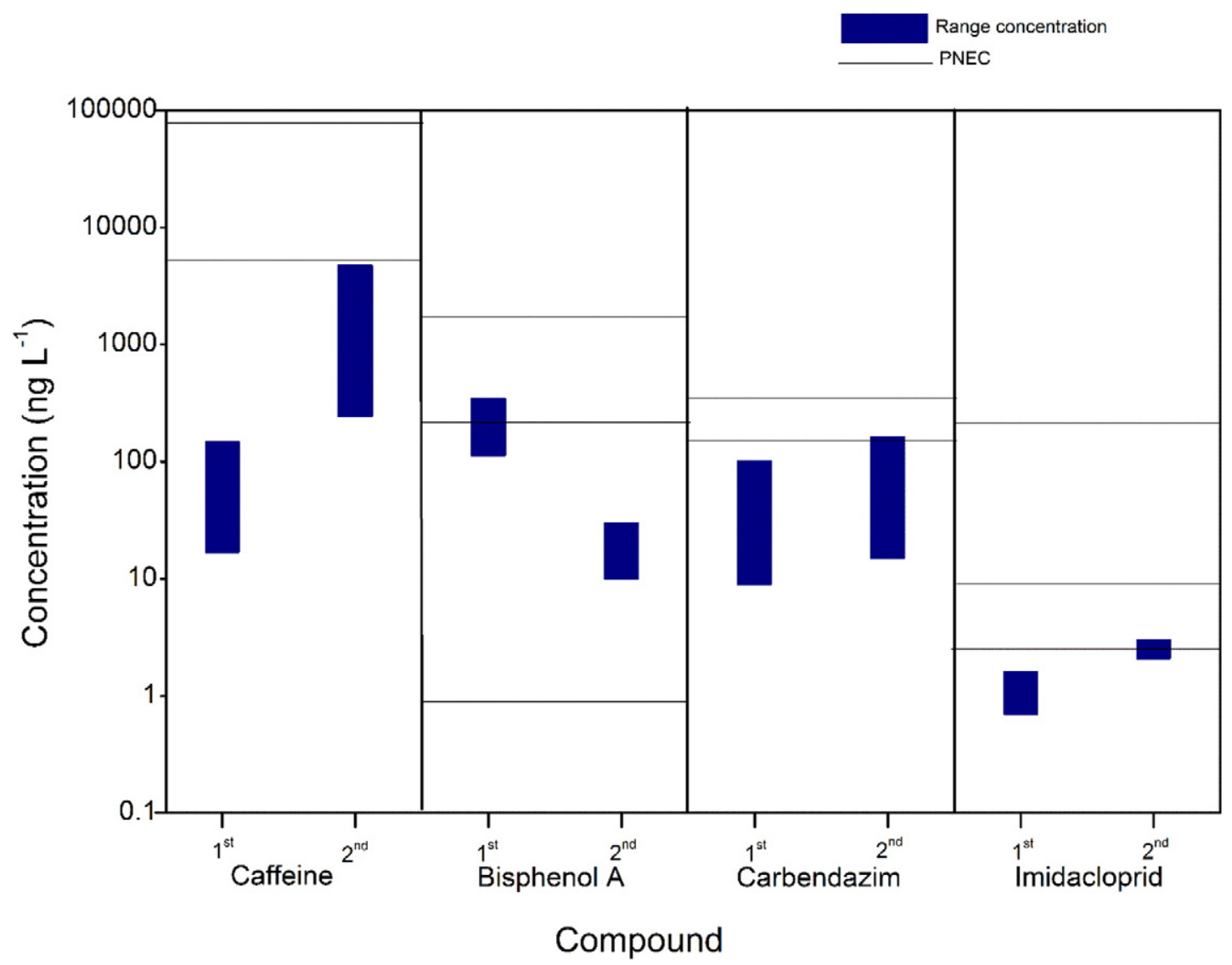

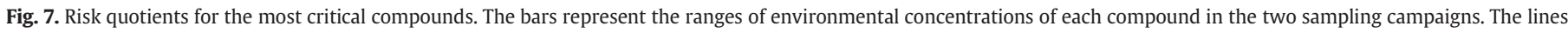

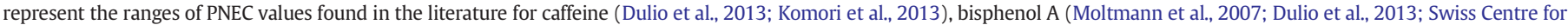

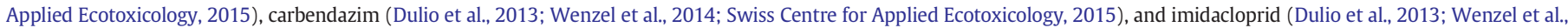
2014; Carvalho et al., 2014).

The existence of different compartments or regions in this reservoir has been described previously by Cardoso-Silva (2008), based on the concentrations of dissolved metals and general indicators of pollution, as well as by Pompêo et al. (2013), based on sediment quality. Cardoso-Silva (2008) identified six different regions in the reservoir during the dry season, and four during the rainy season. Areas A, B and $C$ were clearly distinguished, together with additional areas not studied in the present work. Palma et al. (2014a) reported different compartments in a Portuguese reservoir after considering the presence of pollutants in water and sediments. The observed pattern was attributed to the presence of points of diffuse pollution and the entry of nutrients and metals into the reservoir.

Area A, which was a priori considered less impacted because the low urban pressure, was influenced by inflows from the Embú-Guaçú River, the main natural tributary of the reservoir, therefore the hydrodynamics and biological processes reflected lotic characteristics. This area showed the lowest values for nutrients, Chl. $a$, ammonium, $\mathrm{pH}$, and conductivity, and could be considered mesoeutrophic, based on the concentrations of Chl. $a$ and total P, confirming its initial classification as a less polluted area. The values obtained for TSS in the dry season were the lowest recorded in this study, although in the rainy season the values were similar to those found in area B, possibly due to increased flow and run-off of particulate material from the surrounding areas (natural vegetation and crop fields) as well as regions upstream.

Area B showed the highest values for some of the common indicators of human alteration. This area receives water from the Billings reservoir (Shiromoto et al., 2005), water flows from the Billings in the Parelheiros stream, which is also impacted by untreated domestic sewage from human settlements (Andrade, 2005). This polluted reservoir and sewage from these settlements contribute to the introduction of
P, N, and Chl $a$ into the Guarapiranga system (Sendacz et al., 2005; Matsuzaki, 2007; Cardoso-Silva, 2008; Nishimura et al., 2014). These features provide an explanation for the high concentrations of total $\mathrm{P}$ and Chl. $a$, especially during the dry season when the water volume decreased while the inputs of nutrients from urban activity and sewage remained constant. Consequently, the TSI indicated eutrophic conditions in the rainy season and hypereutrophic conditions in the dry season.

Higher conductivity values were obtained in area B, compared to the other two areas indicating pollution form sewage (Marcé et al., 2008). The concentrations of TSS in area B were also higher than at the other points, with the exception of values obtained in area $A$ in the rainy season. The TSS values could be explained by the inflows of particulate material (organic and inorganic) from the Billings reservoir, algal production, and contributions from run-off and sewage. The high inputs of particulate material, including organic $\mathrm{N}$, could explain the levels of ammonium in this area, which were the highest of the three areas studied and likely originated from the metabolization of dissolved or particulate organic nitrogen.

Area $\mathrm{C}$ could be considered as lentic and the main water body of the reservoir. The theoretical retention time of this area is 180 days (Gemelgo et al., 2008), but depending on operational requirements the retention time can be lower (Occhipinti, 1973; Beyruth, 2000). During the present study, the retention times were 92 days in February and 75 days in September (CETESB, 2015). The sampling points in this area were close to the dam and the water extraction point for water supply and drainage outflow. Area $\mathrm{C}$ was eutrophic in both seasons and was characterized by the highest concentrations of $\mathrm{NO}_{3}^{-}$, while the concentrations of $\mathrm{NO}_{2}^{-}$were similar to those found in area $\mathrm{B}$. The high concentrations of $\mathrm{NO}_{3}^{-}$, relative to the other areas, could be a consequence of 
the nitrification of the $\mathrm{NH}_{4}^{+}$inputs from area $\mathrm{B}$, or the inputs of organic material due to run-off from the highly urbanized margins of area $\mathrm{C}$.

When the concentrations of EPs and pesticides were analyzed using PCA, no clear spatial trends were observed using the combined data for the two campaigns, in contrast to the results obtained using the common indicators of water quality. However, there were indications of a seasonal trend. When PCA was applied separately to the data from the different sampling campaigns, there was clear grouping of the sampling points in the different areas for the dry season, but not for the rainy season (Figs. 5 and 6). For the rainy season, the sampling points of areas A and $C$ appeared intermixed in the graph, suggesting similar characteristics in both water bodies. This was supported by the results of the Welch ANOVA test indicating that there were no significant differences between the areas. In contrast, the sampling points from area B showed greater distances among them, suggesting low homogeneity in this area, and were separated from the points of areas $A$ and $C$.

A possible explanation for these findings could lie in the hydrological behavior of the reservoir in the rainy season and the existence of inputs from diffuse sources in the surrounding areas. Following data from the Sao Paulo's water agency, the main outflow was assumed to be water extraction to supply the water treatment facilities (in area C, SABESP, 2015). During the rainy season, the inflows of water from the tributaries and the Billings reservoir (SABESP, 2015), uncontrolled wastewater discharges, as well as runoff from the catchment (mainly associated to regulated and irregular urban areas), could enhance the hydrodynamics of the reservoir, with water forced to flow throughout the drainage channels of the basin, from the head to the dam and explaining the slightly greater homogeneity in the pollutant distributions, as well as the increased presence of pesticides and EPs in the water.

In the present work, the highest concentrations of pesticides and EPs were found in the rainy season, with some compounds (cocaine, atrazine, ametryn, azoxytrobin, epoxiconazole, and tebuconazole) only being detected or quantified in that period. In tropical and subtropical regions, high rainfall can increase nonpoint pollution from urban or agricultural areas (Qin et al., 2010). You et al. (2015) reported increases in the total concentrations of EPs after rainy periods in a tropical catchment in Singapore, which were attributed to leaks from sewer pipes and runoff from land surfaces.

On the contrary, in the dry season, region B was a hotspot in terms of the concentrations of the EPs and the only significant input of water to the system was from the Billings reservoir, in this area (SABESP, 2015). Pollutant concentrations could be increased by lower precipitation, by constant inputs of untreated wastewater from the human settlements in this area and water from the Billings reservoir (the presence of EPs in this reservoir has been described previously; Almeida and Weber, 2005) and a smaller water volume in this branch during this period (51.8\% of the Guarapiranga capacity, SABESP, 2015).

The compound found at highest concentrations was caffeine, with levels comparable to those measured in polluted rivers in São Paulo State (Montagner and Jardim, 2011; de Sousa et al., 2014; Sodré et al., 2010a,b) and Europe (Kuzmanović et al., 2015a). In the dry season, the concentration of the anti-inflammatory drug diclofenac in area B was similar to levels found in reservoirs affected by urban sewage in Mexico (Félix-Cañedo et al., 2013). Seasonal trends might be associated with varying patterns of consumption and morbidity, as reported elsewhere for diclofenac (Yan et al., 2014; Osorio et al., 2012). Montagner and Jardim (2011) observed significant increases in the concentrations of caffeine and diclofenac in rivers in São Paulo State during the dry period. In the case of caffeine, this pattern was different to those observed for other tropical reservoirs, where its concentration was associated with rain episodes (You et al., 2015).

The concentrations of BPA were notably higher at all points in the rainy season, compared to the dry season. In the rainy season, BPA levels were similar to, or higher than, values for other polluted reservoirs in Brazil and elsewhere (Sodré et al., 2010a; Wang et al., 2015; You et al., 2015). Teuten et al. (2009) suggested the incorrect disposal of plastics and their release into the environment as a source of BPA and other compounds. BPA can be released from plastic materials into water, especially at high temperatures (Sajiki and Yonekubo, 2003). In our study, the sampling points with higher concentrations of BPA were situated in areas $B$ and $C$ (the areas with higher urban soil coverage), even in the dry season. Inefficient collection of urban waste and incorrect disposal results in the presence of plastic material in the reservoir in the form of plastic bottles and other plastic waste in these regions (personal observation).

Benzoylecgonine showed clear temporal and spatial trends, with the highest concentrations in area B in both seasons. The presence of cocaine and benzoylecgonine in European rivers has been attributed to consumption of this drug (Mendoza et al., 2014). Cocaine was not quantified in the dry season, due to the higher LOQ compared to the rainy season; therefore, seasonal trends can't be assessed for the current study. However, seasonal trends in the concentrations of cocaine and its metabolite were observed in European rivers (Mendoza et al., 2014; Huerta-Fontela et al., 2008; Mari et al., 2009), which could have been due to degradation of the compounds by solar irradiation (Mendoza et al., 2014) or microbial activity.

Seasonal trends were also observed for the pesticides. These trends could be related to climatology and seasonal activities in small crop areas, farms and the control of pests in urban areas and gardens situated along the margins and in other areas near the reservoir. Carbendazim was the fungicide found at the highest concentrations, and was quantified at all the sampling points. This compound is widely used in agriculture and veterinary medicine as a fungicide and anthelmintic drug (Davidse, 1987). The highest concentrations were found in area B, especially in the dry season, with the values exceeding the mean concentration ( $82 \mathrm{ng} \mathrm{L}^{-1}$ ) found in several rivers in São Paulo State (Montagner et al., 2014b).

Imidacloprid, a neonicotinoid insecticide used in both domestic and agricultural applications, was detected in the reservoir in both seasons, with slightly higher concentrations in the dry season, but was only quantified in area A, the less urbanized area but with presence of small farms and horticultural crops. Atrazine, tebuconazole, epoxiconazole, and ametryn were detected in all regions at concentrations close to the LOQs, but were only quantified in the rainy season. This suggested inputs due to runoff from adjacent areas, as observed for other pesticides (Haith, 2010; Thuyet et al., 2012). In contrast, the insecticide fipronil was quantified in all areas at similar low concentrations, but only during the dry season, maybe because this insecticide is more related to domestic use against mosquitoes, cockroaches, termites and other pests that appears mainly in the dry season and the treatment of turfs and ornamental plants.

The EDCs were detected in both sampling periods, at concentrations below the LOQs (Table 2). However, the LOQs achieved in this study were higher than those reported in other studies of reservoirs in Brazil and elsewhere (Sodré et al., 2010a,b; Wang et al., 2015; You et al., 2015), so the presence of these compounds in the Guarapiranga reservoir could not be either confirmed or ruled out. The EDC estrone was found previously in other reservoirs in São Paulo State (Sodré et al., 2010a,b) at $12 \mathrm{ng} \mathrm{L}^{-1}$, a concentration lower than reported for a polluted reservoir in China (Wang et al., 2015).

Only 5 of the 13 EPs and pesticides showed correlations with some of the common water quality indicators (Table 4). Imidacloprid showed negative correlations with most of them. Caffeine, a substance used as an indicator of sewage pollution (You et al., 2015; Montagner et al., 2014b; Buerge et al., 2003) did not show any significant correlations with the common water quality parameters. PCA and correlation analysis suggested that the two groups of variables were influenced by different factors, and that these factors varied according to the sampling period. Therefore, the concentrations of the EPs and pesticides provided different and additional information on water quality in the reservoir and possible sources of pollution. Previous studies have suggested that indicators of eutrophication do not always provide information on the 
existence of other environmental pressures such as pollution by EPs or other chemicals. Huerta et al. (2013a) reported a positive correlation between trophic levels and the concentrations of antibiotics in several reservoirs in Catalonia, while residues of the psychiatric drug carbamazepine were found in tissues of fishes collected in a Catalan reservoir considered oligotrophic and with good ecological and chemical status (Huerta et al., 2013b). Similarly, Montagner et al. (2014c) detected triclosan and caffeine at sampling points classified as possessing good water quality, according to the São Paulo State Environmental Agency criteria (CETESB, 2014), indicating pollution by EPs. Therefore, while nutrient enrichment remains a risk factor for chemical and biological quality in freshwater reservoirs (Smith and Schindler, 2009), EPs and other unregulated pollutants can also impair chemical quality in these systems (Pérez et al., 2010; Palma et al., 2010). The concentration of caffeine has been correlated with estrogenic activity and the presence of other EPs (Buerge et al., 2003; Montagner et al., 2014b), suggesting that the routine analysis of this compound in monitoring programs might provide an inexpensive and reliable indication of the presence of unregulated pollutants in freshwater bodies. The São Paulo State Environmental Agency recently included the determination of caffeine as a parameter for monitoring in water bodies (CETESB, 2015) being the first Brazilian agency doing it.

The fluxes, hydrodynamics, and total volume of the reservoir influenced the observed patterns in the presence and concentrations of both groups of variables, although the differences could also be affected by other factors such as assimilation by organisms, biodegradation, and photodegradation, among other chemical and physical processes (Gurr and Reinhard, 2006; Acuña et al., 2015). However, not all substances have the same photo- and biodegradation (or bioassimilation) patterns, due to their different molecular structures, and their distributions in a reservoir are a function of their individual half-lives and transport due to flow. For example, Tixier et al. (2003) calculated half-lives exceeding 8 days for different pharmaceuticals in a European lake. On the contrary, the availability of nutrients in the water column and through the different compartments of a reservoir is strongly dependent on biological processes involving nutrient cycling and metabolization by organisms, which can cause faster disappearance of nutrients and the formation of gradients from sources of nutrient pollution to areas that are less impacted (Ensign and Doyle, 2006).

\subsection{Risk assessment}

When substances not commonly included in monitoring programs (such as EPs and pesticides) are included in water analysis, unexpected toxicological risks in water bodies can be revealed, as has been demonstrated in several studies (Ginebreda et al., 2010; Moschet et al., 2014; Palma et al., 2014b; and Kuzmanović et al., 2015a,b).

Although no risk to human health in raw water from the reservoir was observed, carbendazim, imidacloprid, and BPA showed risks to the biota. In one season, the concentrations of caffeine were very close to the PNEC value, according to the RQ criterion. However, these results are based on certain assumptions. The values used for calculation of the PNECs were based on toxicity tests under controlled conditions using model organisms or systems (see Table $3 \mathrm{SM}$ ). In the case of natural freshwater ecosystems, it is necessary to consider that (a) chemical substances are not present in isolation, but in complex mixtures, enabling synergistic or antagonistic interactions (De Zwart and Posthuma, 2005; Carvalho et al., 2014); (b) the adverse effects of chemical pollutants may depend on the prevailing environmental (trophic state, temperature, conductivity, solar irradiation, dissolved organic carbon, amongst others) and biological conditions (parasitism, predation, invasive species amongst others) (Holmstrup et al., 2010; Fischer et al., 2013); (c) chronic exposure at low concentrations is a more realistic scenario than acute short-term exposure (Calow and Forbes, 2003; Eggen et al., 2004); (d) natural populations and communities can have different sensitivities according to genetic background or species composition (Bickham et al., 2000; Clements and Rohr, 2009); (e) little information exists on the sensitivity of tropical freshwater organisms; therefore, these organisms may not be adequately represented, by the standard aquatic test species from other climatic regions (Kwok et al., 2007).

In studies using experimental or natural communities, carbendazim and imidacloprid have shown different toxicological thresholds. Effects of imidacloprid at concentrations in the range of $10 \mathrm{ng} \mathrm{L}^{-1}$ on macroinvertebrate communities have been suggested for European rivers (Van Dijk et al., 2013). In contrast, experiments in a tropical region with outdoor microcosms composed of zooplankton, phytoplankton, and benthic macroinvertebrates resulted in NOEC values for the community of $3.3 \mu \mathrm{g} \mathrm{L}^{-1}$ (carbendazim) and $0.6 \mu \mathrm{g} \mathrm{L}^{-1}$ (imidacloprid) after 2 weeks of exposure (Daam et al., 2009), with insects being the most sensitive organisms (Posthuma-Doodeman, 2008).

BPA was one of the substances found at higher concentrations in the Guarapiranga reservoir. This compound has been described as a potential EDC (Rubin, 2011) and Wright-Walters et al. (2011) reviewed the literature on the effects of BPA on several freshwater organisms. In this review was found effective concentrations in the range of ng to $\mathrm{mg} \mathrm{L}^{-1}$ and effects on reproduction, growth and survival.

Caffeine was the substance detected at highest concentrations in the reservoir. Considering the values reported by Komori et al. (2013) (Table 2), there was the potential for adverse effects on biota in area $B$ during the dry season $(\mathrm{RQ}=0.91)$. Other studies have used PNEC values lower than the value used in our study.

The possible harmful effects of illicit drugs in ecosystems have been highlighted in recent reviews by Rosi-Marshall et al. (2015) and Pal et al. (2013), which also point out the need for more studies of the presence of these substances and their potential effects. Cocaine and its metabolite benzoylecgonine were the other two substances quantified in significant concentrations in the Guarapiranga reservoir. No PNECs were found for these substances in the literature, and few data have been published. Experimental studies found that at concentrations of $40 \mathrm{ng} \mathrm{L}^{-1}$, cocaine caused cytotoxicity in zebra mussel after $72 \mathrm{~h}$ of exposure under experimental conditions (Binelli et al., 2012). At $500 \mathrm{ng}$ $\mathrm{L}^{-1}$, the metabolite induced the same response after 11 days of exposure, while evidence of alterations in antioxidant enzyme activities was observed at the same concentration after 4 days of exposure (Parolini et al., 2013). In the case of fish (European eel, Anguilla anguilla), sublethal effects such as histological alterations, changes in the endocrine system, and accumulation in tissues were observed after exposure to $20 \mathrm{ng} \mathrm{L}^{-1}$ of cocaine for 30 days (Capaldo et al., 2012; Gay et al., 2013, 2015). Further information is needed concerning the effects of these substances in other groups of organisms, but the concentrations reported to cause effects were in the same order of magnitude of those found in area B of the Guarapiranga reservoir $\left(12 \mathrm{ng} \mathrm{L}^{-1}\right.$ for cocaine and $179 \mathrm{ng} \mathrm{L}^{-1}$ for benzoylecgonine).

The data cited suggest potential for the substances analyzed in the Guarapiranga reservoir to impair freshwater organisms, at the concentrations detected, but more information on the effects of these substances on autochthonous species and communities under natural conditions is needed in order to obtain a satisfactory risk assessment. Despite the possible risks associated with some of the substances studied, the routine bioassays performed during 2014 by the São Paulo State Environmental Agency (CETESB), using water from the reservoir (areas $\mathrm{B}$ and $\mathrm{C}$ ), did not show any toxicological responses in the cladoceran Ceriodaphnia dubia, even for area B (Parelheiros). However, mutagenic activity (using the Ames' test) was detected once in that year (CETESB, 2015). The use of bioassays is an excellent way to detect the toxicological effects of chemical mixtures (Bonada et al., 2006). However, the absence of chronic or acute toxicological effects on cladocerans does not exclude the possibility of other kinds of impairments at lower levels of biological organization (as suggested by the presence of mutagenic effects), or effects in native organisms with longer life cycles under chronic exposure (such as fishes). In the latter case, 
organisms that are chronically exposed can be valuable indicators of sublethal effects and the bioaccumulation of different toxic substances has been demonstrated before (Benejam et al., 2010; Suárez-Serrano et al., 2010; Faria et al., 2010a,b; González-González et al., 2014). Santos et al. (2004) detected histological damage in the liver of Oreochromis niloticus cultured in the Guarapiranga reservoir, which was attributed to the presence of toxic substances in the water of the reservoir.

The evaluation of the presence and concentrations of the EPs and pesticides in the Guarapiranga reservoir, with assessment of the potential risks, constitutes a first step in understanding the impacts of these pollutants in the reservoir. Further research concerning the real effects on the ecosystem should include community analysis, the use of biomarkers (understood as any measurable molecular, cellular, histological, physiological, or behavioral response; Depledge, 1994), in situ bioassays, and bioassays with other test organisms (Faria et al., 2010a, b; Rivetti et al., 2015).

\section{Conclusions}

Although long-term monitoring is necessary to confirm that the results obtained in our study represent a consistent pattern, the findings provide valuable information for the purposes of water management and risk assessment. The data indicated that in Guarapiranga, EPs and pesticides did not always present the same behavior as the common indicators of human impact. The presence and concentrations of the EPs and pesticides showed different patterns, depending on the sampling season. Possible explanations included seasonal changes in the water volume in the reservoir, as well as in rain frequency and intensity, which affected the inputs of pollution from diffuse sources and altered the flows and hydrodynamics in the reservoir. Biological, physical, and chemical processes caused differential rates of degradation or elimination of nutrients and other pollutants in the reservoir. In addition, potential risks were identified for substances not currently included in São Paulo State monitoring programs or statutory regulations. The findings could be of interest to water managers and policy makers, and help to improve monitoring programs and policies for the protection of freshwater organisms and resources.

Supplementary data to this article can be found online at http://dx. doi.org/10.1016/j.scitotenv.2016.09.210.

\section{Acknowledgments}

This research was funded by the São Paulo State Research Foundation (FAPESP, projects 2012/16420-6, 2012/11890-4, 2014/22581-0, and 2014/24740-6). Special thanks to Philipe Riskalla Leal, Bruno De Paes, Geison Castro, Sheila Cardoso-Silva and Frederico Beghelli who collaborated in sampling campaigns and sample analysis. Thanks to three anonymous reviewers who improved this article with their suggestions and comments.

\section{References}

Acuña, V., von Schiller, D., García-Galán, M.J., Rodríguez-Mozaz, S., Corominas, L., Petrovic, M., Poch, M., Barceló, D., Sabater, S., 2015. Occurrence and in-stream attenuation of wastewater-derived pharmaceuticals in Iberian rivers. Sci. Total Environ. 503, 133-141.

Almeida, G.A.D., Weber, R.R., 2005. Fármacos na represa Billings. Revista Saúde e Ambiente 6 (2), 7-13

Andrade, A.A.D.S., 2005. Análise da eficiência da várzea do Ribeirão Parelheiros na melhoria de qualidade das águas que afluem à Represa do Guarapiranga, São Paulo PhD dissertation Universidade de São Paulo, São Paulo. Brazil.

Azevedo, L.B., van Zelm, R., Leuven, R.S., Hendriks, A.J., Huijbregts, M.A., 2015a. Combined ecological risks of nitrogen and phosphorus in European freshwaters. Environ. Pollut. 200, 85-92.

Azevedo, D.J.S., Barbosa, J.E.L., Gomes, W.I.A., Porto, D.E., Marques, J.C., Molozzi, J., 2015b. Diversity measures in macroinvertebrate and zooplankton communities related to the trophic status of subtropical reservoirs: contradictory or complementary responses? Ecol. Indic. 50, 135-149.
Barbosa, A.M., de Solano, L.M., Umbuzeiro, G.D.A., 2015. Pesticides in drinking water-the Brazilian monitoring program. Frontiers in Public Health 3.

Begliutti, B., Buscarinu, P., Marras, G., Sechi, G.M., Sulis, A., 2007. Reservoirs water-quality characterization for optimization modelling under drought conditions part I-reservoirs trophic state characterization. Methods and Tools for Drought Analysis and Management. Springer, Netherlands, pp. 239-261.

Benejam, L., Benito, J., García-Berthou, E., 2010. Decreases in condition and fecundity of freshwater fishes in a highly polluted reservoir. Water Air Soil Pollut. 210 (1-4), 231-242.

Beyruth, Z., 2000. Periodic disturbances, trophic gradient and phytoplankton characteristics related to cyanobacterial growth in Guarapiranga reservoir, São Paulo state, Brazil. Hydrobiologia 424 (1-3), 51-65.

Bickham, J.W., Sandhu, S., Hebert, P.D., Chikhi, L., Athwal, R., 2000. Effects of chemical contaminants on genetic diversity in natural populations: implications for biomonitoring and ecotoxicology. Mutation research/Reviews in Mutation research 463 (1), 33-51.

Binelli, A., Pedriali, A., Riva, C., Parolini, M., 2012. Illicit drugs as new environmental pollutants: cyto-genotoxic effects of cocaine on the biological model Dreissena polymorpha. Chemosphere 86 (9), 906-911.

Bonada, N., Prat, N., Resh, V.H., Statzner, B., 2006. Developments in aquatic insect biomonitoring: a comparative analysis of recent approaches. Annu. Rev. Entomol. 51, 495-523.

Braga, B.P.F., Porto, M.F.A., Silva, R.T., 2006. Water management in metropolitan São Paulo. Water Resour. Dev. 22, 337-352.

Brand, W., de Jongh, C.M., van der Linden, S.C., Mennes, W., Puijker, L.M., van Leeuwen, C.J., van Wezel, A.P., Schriks, M., Heringa, M.B., 2013. Trigger values for investigation of hormonal activity in drinking water and its sources using CALUX bioassays. Environ. Int. 55, 109-118

Brasilian Ministry of Health, 2011. Portaria MS No 2.914, de 12 de Dezembro de 2011. Ministry of Health, Brasília, Brasil.

Bucci, M.M.H.S., Delgado, F.E.D.F., de Oliveira, L.F.C., 2015. Water quality and trophic state of a tropical urban reservoir for drinking water supply (Juiz de Fora, Brazil). Lake and Reservoir Management 31 (2), 134-144.

Buerge, I.J., Poiger, T., Müller, M.D., Buser, H.R., 2003. Caffeine, an anthropogenic marker for wastewater contamination of surface waters. Environ. Sci. Technol. 37 (4), 691-700.

Calow, P., Forbes, V.E., 2003. Peer reviewed: does ecotoxicology inform ecological risk assessment? Environ. Sci. Technol. 37 (7), 146A-151A.

Capaldo, A., Gay, F., Maddaloni, M., Valiante, S., De Falco, M., Lenzi, M., Laforgia, V., 2012. Presence of cocaine in the tissues of the European eel, Anguilla anguilla, exposed to environmental cocaine concentrations. Water Air Soil Pollut. 223 (5), 2137-2143.

Cardoso-Silva, S., 2008. Heterogeneidade espacial e a qualidade das águas superficiais do Reservatório Guarapiranga (São Paulo-SP-Brasil) PhD dissertation Instituto de Biociências, Universidade de São Paulo, São Paulo. Brazil in Portuguese.

Cardoso-Silva, S., de Lima Ferreira, P.A., Moschini-Carlos, V., Figueira, R.C.L., Pompêo, M., 2016. Temporal and spatial accumulation of heavy metals in the sediments at Paiva Castro reservoir (São Paulo, Brazil). Environ. Earth Sci. 75 (1), 1-16.

Carvalho, R.N., Arukwe, A., Ait-Aissa, S., Bado-Nilles, A., Balzamo, S., Baun, A., Creusot, N., 2014. Mixtures of chemical pollutants at European legislation safety concentrations: how safe are they? Toxicol. Sci. 141 (1), 218-233.

CETESB, Companhia Ambiental do Estado de São Paulo, 2014. 2013 Qualidade das águas superficiais no estado de São Paulo. Companhia Ambiental do Estado de São Paulo, São Paulo. Brasil.

CETESB, Companhia Ambiental do Estado de São Paulo, 2015. 2014 Qualidade das águas superficiais no estado de São Paulo. Companhia Ambiental do Estado de São Paulo, São Paulo. Brasil.

Clements, W.H., Rohr, J.R., 2009. Community responses to contaminants: using basic ecological principles to predict ecotoxicological effects. Environ. Toxicol. Chem. 28 (9), $1789-1800$

Clements, R., Koh, L.P., Lee, T.M., Meier, R., Li, D., 2006. Importance of reservoirs for the conservation of freshwater molluscs in a tropical urban landscape. Biol. Conserv. 128 (1), 136-146.

CONAMA, Conselho Nacional do Meio Ambiente, 2005. Resolução CONAMA 357. Conselho Nacional do Medio Ambiente, Brasília, DF. Brasil.

Cunha, D.G.F., do Carmo Calijuri, M., Lamparelli, M.C., 2013. A trophic state index for tropical/subtropical reservoirs (TSI tsr). Ecol. Eng. 60, 126-134.

Daam, M.A., Satapornvanit, K., Van den Brink, P.J., Nogueira, A.J., 2009. Sensitivity of macroinvertebrates to carbendazim under semi-field conditions in Thailand: implications for the use of temperate toxicity data in a tropical risk assessment of fungicides. Chemosphere 74 (9), 1187-1194.

Davidse, L.C., 1987. Biochemical aspects of benzimidazole fungicides-action and resistance. In: Lyr, H. (Ed.), Modern Selective Fungicides-Properties, Applications, Mechanisms of Action. Longman, London, pp. 245-257.

de A. Umbuzeiro, G., 2012. Guia de Potabilidade Para Substâncias Químicas. ABES-SP Associação Brasileira de Engenharia Sanitária e Ambiental, Limiar, São Paulo, Brazil.

de Morais, L.C., Guandique, M.E.G., 2015. Reservatorios em metrópoles e tratamentos de seus efluentes. In: Pompêo, et al. (Eds.), Ecologia de reservatórios e interfaces. Instituto de Biociências da Universidade de São Paulo, São Paulo, Brazil, São Paulo.

de Sousa, D.N.R., Mozeto, A.A., Carneiro, R.L., Fadini, P.S., 2014. Electrical conductivity and emerging contaminant as markers of surface freshwater contamination by wastewater. Sci. Total Environ. 484, 19-26.

De Zwart, D., Posthuma, L., 2005. Complex mixture toxicity for single and multiple species: proposed methodologies. Environ. Toxicol. Chem. 24 (10), 2665-2676.

Depledge, M.H., 1994. The rational basis for the use of biomarkers as ecotoxicological tools. Nondestructive biomarkers in vertebrates 271-295

Dulio, V., von der Ohe, P., Agerstrand, M., Amalric, L., Andres, S., Bláha, L., Brack, W., Brostrom, E., Budzinski, H., Fisher, S., Franklin, J., Hebert, A., Hollender, J., Ingrand, 
V., James-Casas, A., Keller, M., Očenášková, V., Peijnenburg, W., Rábová, Z., Roose, P., Ruedel, H., Schriks, M., Schudoma, D., Slobodník, J., Staub, P.F., de Voogt, P., 2013. Passive Sampling Interlaboratory Study - Data Evaluation. NORMAN Association, France.

ECC (European Community Commission), 2000. Commission Directive 2000/60/EC of the European Parliament and the council establishing the framework for community action in the field of water policy. Off. J. Eur. Union; OJL 327.

ECC (European Community Commission), 2009. Commission Directive 2009/90/EC of the European Parliament and the Council, technical specifications for chemical analysis and monitoring of water status. Off. J. Eur. Union 201. OJL.

Eggen, R.I., Behra, R., Burkhardt-Holm, P., Escher, B.I., Schweigert, N., 2004. Peer reviewed: challenges in ecotoxicology. Environ. Sci. Technol. 38 (3), 58A-64A.

Ellis, J.B., Mitchell, G., 2006. Urban diffuse pollution: key data information approaches for the Water Framework Directive. Water and Environment Journal 20 (1), 19-26.

Ensign, S.H., Doyle, M.W., 2006. Nutrient spiraling in streams and river networks. Journal of Geophysical Research: Biogeosciences (2005-2012) 111 (G4).

Faria, M., Huertas, D., Soto, D.X., Grimalt, J.O., Catalan, J., Riva, M.C., Barata, C., 2010a. Contaminant accumulation and multi-biomarker responses in field collected zebra mussels (Dreissena polymorpha) and crayfish (Procambarus clarkii), to evaluate toxicological effects of industrial hazardous dumps in the Ebro river (NE Spain). Chemosphere 78 (3), 232-240.

Faria, M., López, M.A., Díez, S., Barata, C., 2010b. Are native naiads more tolerant to pollution than exotic freshwater bivalve species? An hypothesis tested using physiological responses of three species transplanted to mercury contaminated sites in the Ebro River (NE, Spain). Chemosphere 81 (10), 1218-1226.

Faustino, S.B., Fontana, L., Bartozek, E.C.R., Bicudo, C.E.D.M., Bicudo, D.D.C., 2016. Composition and distribution of diatom assemblages from core and surface sediments of a water supply reservoir in Southeastern Brazil. Biol. Neonate 16 (2).

Félix-Cañedo, T.E., Durán-Álvarez, J.C., Jiménez-Cisneros, B., 2013. The occurrence and distribution of a group of organic micropollutants in Mexico City's water sources. Sci. Total Environ. 454, 109-118.

Fischer, B.B., Pomati, F., Eggen, R.I., 2013. The toxicity of chemical pollutants in dynamic natural systems: the challenge of integrating environmental factors and biological complexity. Sci. Total Environ. 449, 253-259.

Fontana, L., Albuquerque, A.L.S., Brenner, M., Bonotto, D.M., Sabaris, T.P., Pires, M.A. Cotrim, M.E.B., Bicudo, D.C., 2014. The eutrophication history of a tropical water supply reservoir in Brazil. J. Paleolimnol. 51, 29-43.

García-Reiriz, A.G., Olivieri, A.C., Teixidó, E., Ginebreda, A., Tauler, R., 2014. Chemometric modeling of organic contaminant sources in surface waters of a Mediterranean river basin. Environmental Science: Processes \& Impacts 16 (1), 124-134.

Gay, F., Ferrandino, I., Monaco, A., Cerulo, M., Capasso, G., Capaldo, A., 2015. Histological and hormonal changes in the European eel (Anguilla anguilla) after exposure to environmental cocaine concentration. J. Fish Dis. In press.

Gay, F., Maddaloni, M., Valiante, S., Laforgia, V., Capaldo, A., 2013. Endocrine disruption in the European eel, Anguilla anguilla, exposed to an environmental cocaine concentration. Water Air Soil Pollut. 224 (5), 1-11.

Gemelgo, M.C., Sant'Anna, C.L., Tucci, A., Barbosa, H.R., 2008. Population dynamics of Cylindrospermopsis raciborskii (Woloszynska) Seenayya \& Subba Raju, a cyanobacteria toxic species, in watersupply reservoirs in São Paulo, Brazil. Hoehnea 35 (2), 297-307.

Ginebreda, A., Muñoz, I., de Alda, M.L., Brix, R., López-Doval, J., Barceló, D., 2010. Environmental risk assessment of pharmaceuticals in rivers: relationships between hazard indexes and aquatic macroinvertebrate diversity indexes in the Llobregat River (NE Spain). Environ. Int. 36 (2), 153-162.

González-González, E.D., Gómez-Oliván, L.M., Galar-Martínez, M., Vieyra-Reyes, P., IslasFlores, H., García-Medina, S., Jiménez-Vargas, J.M., Razo-Estrada, C., Pérez-Pastén, R., 2014. Metals and nonsteroidal anti-inflammatory pharmaceuticals drugs present in water from Madín reservoir (Mexico) induce oxidative stress in gill, blood, and muscle of common carp (Cyprinus carpio). Arch. Environ. Contam. Toxicol. 67 (2), 281-295.

Gurr, C.J., Reinhard, M., 2006. Harnessing natural attenuation of pharmaceuticals and hormones in rivers. Environ. Sci. Technol. 40 (9), 2872-2876.

Haith, D.A., 2010. Ecological risk assessment of pesticide runoff from grass surfaces. Environ. Sci. Technol. 44 (16), 6496-6502.

Hall, M.J., Ellis, J.B., 1985. Water quality problems of urban areas. GeoJournal 11 (3), 265-275.

Health Canada, 2014. Guidelines for Canadian drinking water quality-summary table. Water and Air Quality Bureau, Healthy Environments and Consumer Safety Branch. Health Canada, Ottawa, Canada.

Hering, D., Borja, A., Carstensen, J., Carvalho, L., Elliott, M., Feld, C.K., Heiskanenf, A.S., Johnsong, R.K., Moeh, J., Ponti, D., Solheim, A.L., van de Bund, W., 2010. The European Water Framework Directive at the age of 10: a critical review of the achievements with recommendations for the future. Sci. Total Environ. 408 (19), 4007-4019.

Holmstrup, M., Bindesbøl, A.M., Oostingh, G.J., Duschl, A., Scheil, V., Köhler, H.R., Loureiro, S., Soares, A.M.V.M., Ferreira, A.L.G., Kienle, C., Gerhardt, A., Laskowski, R., Kramarz, P.E., Bayley, M., Svendsen, C., Spurgeon, D.J., 2010. Interactions between effects of environmental chemicals and natural stressors: a review. Sci. Total Environ. 408 (18), 3746-3762.

Huerta, B., Jakimska, A., Gros, M., Rodríguez-Mozaz, S., Barceló, D., 2013b. Analysis of multi-class pharmaceuticals in fish tissues by ultra-high-performance liquid chromatography tandem mass spectrometry. J. Chromatogr. A 1288, 63-72.

Huerta, B., Marti, E., Gros, M., López, P., Pompêo, M., Armengol, J., Barceló, D., Balcázar, J.L., Rodríguez-Mozaz, S., Marcé, R., 2013a. Exploring the links between antibiotic occurrence, antibiotic resistance, and bacterial communities in water supply reservoirs. Sci. Total Environ. 456, 161-170.
Huerta-Fontela, M., Galceran, M.T., Ventura, F., 2008. Stimulatory drugs of abuse in surface waters and their removal in a conventional drinking water treatment plant. Environ. Sci. Technol. 42 (18), 6809-6816 2008.

Isidori, M., Lavorgna, M., Nardelli, A., Pascarella, L., Parrella, A., 2005. Toxic and genotoxic evaluation of six antibiotics on non-target organisms. Sci. Total Environ. 346 (1), 87-98.

Jeffrey, S.W., Humphrey, G.F., 1975. New spectrophotometric equations for determining chlorophyll $a, b, c 1$ and $c 2$ in higher plants, algae and natural phytoplankton. Biochem. Physiol. Pflanz. 167, 191-194.

Komori, K., Suzuki, Y., Minamiyama, M., Harada, A., 2013. Occurrence of selected pharmaceuticals in river water in Japan and assessment of their environmental risk. Environ. Monit. Assess. 185 (6), 4529-4536.

Koroleff, F., 1976. Determination of nutrients Org In: Grasshoff, K. (Ed.), Methods of Seawater Analysis. Verlag Chemie, Weinhein New York. USA.

Kuzmanović, M., Ginebreda, A., Petrović, M., Barceló, D., 2015a. Risk assessment based prioritization of 200 organic micropollutants in 4 Iberian rivers. Sci. Total Environ. 503, 289-299.

Kuzmanović, M., López-Doval, J.C., De Castro-Català, N., Guasch, H., Petrović, M., Muñoz, I Ginebreda, A., Barceló, D., 2015b. Ecotoxicological risk assessment of chemical pollution in four Iberian river basins and its relationship with the aquatic macroinvertebrate community status. Science of the Total Environment.

Kwok, K.W., Leung, K.M., Lui, G.S., Chu, V.K., Lam, P.K., Morritt, D., Maltby, L., Brock, T.C.M. Van den Brink, P.J., Warne, M.S.J., Crane, M., 2007. Comparison of tropical and temperate freshwater animal species acute sensitivities to chemicals: implications for deriving safe extrapolation factors. Integr. Environ. Assess. Manag. 3 (1), 49-67.

Lehner, B., Liermann, C.R., Revenga, C., Vörösmarty, C., Fekete, B., Crouzet, P., Döll, P., Endejan, M., Frenken, K., Wisser, D., 2011. High-resolution mapping of the world's reservoirs and dams for sustainable river-flow management. Front. Ecol. Environ. 9 (9), 494-502.

Liu, H., Pan, D., Chen, P., 2015. A two-year field study and evaluation of water quality and trophic state of a large shallow drinking water reservoir in Shanghai, China. Desalin. Water Treat. 1-10.

Lorenzen, C.J., 1967. Determination of chlorophyll and pheo-pigments: spectrophotometric equations. Limnol. Oceanogr. 12 (2), 343-346.

Mackereth, F.J.H., Heron, J., Talling, J.F., 1978. Water analysis: some revised methods for limnologists. Freshwater Biological Association 36. Institute of Freshwater Biology The Windermere Laboratory, The Ferry House, Ambleside, Cumbria, UK.

Marcé, R., Moreno-Ostos, E., López, P., Armengol, J., 2008. The role of allochthonous inputs of dissolved organic carbon on the hypolimnetic oxygen content of reservoirs. Ecosystems 11, 1035-1053.

Mari, F., Politi, L., Biggeri, A., Accetta, G., Trignano, C., Di Padua, M., Bertol, E., 2009. Cocaine and heroin in waste water plants: a 1-year study in the city of Florence, Italy. Forensic Sci. Int 189 (1), 88-92.

Mariani, C.F., Pompêo, M.L., 2008. Potentially bioavailable metals in sediment from a tropical polymictic environment-Rio Grande reservoir, Brazil. J. Soils Sediments 8 (5), 284-288.

Martinez, M., Peñuela, G.A., 2013. Analysis of triclosan and 4n-nonylphenol in Colombian reservoir water by gas chromatography-mass spectrometry. Water and Environment Journal 27 (3), 387-395.

Matsuzaki, M., 2007. Transposição das águas do braço Taquacetuba da represa Billings para a represa Guarapiranga: aspectos relacionados à qualidade de água para abastecimento PhD dissertation Faculdade de Saúde Pública. Departamento de Saúde Ambiental Universidade de São Paulo, São Paulo. Brazil.

Mendoza, A., Rodríguez-Gil, J.L., González-Alonso, S., Mastroianni, N., de Alda, M.L., Barceló, D., Valcárcel, Y., 2014. Drugs of abuse and benzodiazepines in the Madrid region (Central Spain): seasonal variation in river waters, occurrence in tap water and potential environmental and human risk. Environ. Int. 70, 76-87.

Meyer, J.L., Paul, M.J., Taulbee, W.K., 2005. Stream ecosystem function in urbanizing landscapes. J. N. Am. Benthol. Soc. 24 (3), 602-612.

Molozzi, J., Feio, M.J., Salas, F., Marques, J.C., Callisto, M., 2012. Development and test of a statistical model for the ecological assessment of tropical reservoirs based on benthic macroinvertebrates. Ecol. Indic. 23, 155-165.

Moltmann, J.F., Liebig, M., Knacker, T., Keller, M., Scheurer, M., Ternes, T., 2007. Relevance of Endocrine Disrupting Substances and Pharmaceuticals in Surface Waters. UBA-FB, 1032, 130. Dessau, Deutschland.

Montagner, C.C., Jardim, W.F., 2011. Spatial and seasonal variations of pharmaceuticals and endocrine disruptors in the Atibaia River, São Paulo state (Brazil). J. Braz. Chem. Soc. 22 (8), 1452-1462.

Montagner, C.C., Jardim, W.F., Von der Ohe, P.C., Umbuzeiro, G.A., 2014c. Occurrence and potential risk of triclosan in freshwaters of São Paulo, Brazil-the need for regulatory actions. Environ. Sci. Pollut. Res. 21 (3), 1850-1858.

Montagner, C.C., Umbuzeiro, G.A., Pasquini, C., Jardim, W.F., 2014b. Caffeine as an indicator of estrogenic activity in source water. Environmental Science: Processes \& Impacts 16 (8), 1866-1869.

Montagner, C.C., Vidal, C., Acayaba, R.D., Jardim, W.F., Jardim, I.C., Umbuzeiro, G.A., 2014a Trace analysis of pesticides and an assessment of their occurrence in surface and drinking waters from the state of São Paulo (Brazil). Anal. Methods 6 (17), 6668-6677.

Moschet, C., Wittmer, I., Simovic, J., Junghans, M., Piazzoli, A., Singer, H., Stamm, C., Leu, C., Hollender, J., 2014. How a complete pesticide screening changes the assessment of surface water quality. Environ. Sci. Technol. 48 (10), 5423-5432.

Moschini-Carlos, V., Dörr, F., de Freitas, L.G., Pinto, E., Pompêo, M.L., Bortoli, S., Nishimura, P.Y., 2009. Cyanobacteria and cyanotoxin in the Billings reservoir (São Paulo, SP, Brazil). Limnetica 28, 0273-0282.

Murray, K.E., Thomas, S.M., Bodour, A.A., 2010. Prioritizing research for trace pollutants and emerging contaminants in the freshwater environment. Environ. Pollut. 158 (12), 3462-3471. 
New Zealand Ministry of Health, 2008. Drinking-Water Standards for New Zealand 2005 (Revised 2008). Ministry of Health, Wellington, New Zealand.

Nilsson, C., Reidy, C.A., Dynesius, M., Revenga, C., 2005. Fragmentation and flow regulation of the world's large river systems. Science 308 (5720), 405-408.

Nishimura, P.Y., do Amaral Meirinho, P., Carlos, V.M., Pompêo, M., 2014. Does the plankton community follow the horizontal water quality heterogeneity in a tropical urban reservoir (Guarapiranga reservoir, São Paulo, Brazil)? Limnetica 33 (2), 263-280.

Occhipinti, A.G., 1973. Modelo de qualidade de água do Reservatório Guarapiranga. USP EESC. VII CONGRESSO BRASILEIRO DE ENGENHARIA SANITÁRIA, Anais. Salvador, Bahia, Brazil.

Osorio, V., Marcé, R., Pérez, S., Ginebreda, A., Cortina, J.L., Barceló, D., 2012. Occurrence and modeling of pharmaceuticals on a sewage-impacted Mediterranean river and their dynamics under different hydrological conditions. Sci. Total Environ. 440, 3-13.

Paggi, J.C., Mendoza, R.O., Debonis, C.J., de Paggi, S.B.J., 2001. A simple and inexpensive trap-tube sampler for zooplankton collection in shallow waters. Hydrobiologia 464 (1-3), 45-49.

Pal, A., Gin, K.Y.H., Lin, A.Y.C., Reinhard, M., 2010. Impacts of emerging organic contaminants on freshwater resources: review of recent occurrences, sources, fate and effects. Sci. Total Environ. 408 (24), 6062-6069.

Pal, R., Megharaj, M., Kirkbride, K.P., Naidu, R., 2013. Illicit drugs and the environment-a review. Sci. Total Environ. 463, 1079-1092.

Palma, P., Köck-Schulmeyer, M., Alvarenga, P., Ledo, L., Barbosa, I.R., de Alda, M.L., Barceló, D., 2014b. Risk assessment of pesticides detected in surface water of the Alqueva reservoir (Guadiana basin, southern of Portugal). Sci. Total Environ. 488, 208-219.

Palma, P., Ledo, L., Soares, S., Barbosa, I.R., Alvarenga, P., 2014a. Spatial and temporal variability of the water and sediments quality in the Alqueva reservoir (Guadiana Basin; southern Portugal). Sci. Total Environ. 470, 780-790.

Palma, P., Alvarenga, P., Palma, V., Matos, C., Fernandes, R.M., Soares, A., Barbosa, I.R., 2010 Evaluation of surface water quality using an ecotoxicological approach: a case study of the Alqueva reservoir (Portugal). Environ. Sci. Pollut. Res. 17 (3), 703-716.

Parolini, M., Pedriali, A., Riva, C., Binelli, A., 2013. Sub-lethal effects caused by the cocaine metabolite benzoylecgonine to the freshwater mussel Dreissena polymorpha. Sci. Total Environ. 444, 43-50.

Paul, M.J., Meyer, J.L., 2001. Streams in the urban landscape. Annu. Rev. Ecol. Syst. 333-365.

Pérez, J.R., Loureiro, S., Menezes, S., Palma, P., Fernandes, R.M., Barbosa, I.R., Soares, A.M., 2010. Assessment of water quality in the Alqueva reservoir (Portugal) using bioassays. Environ. Sci. Pollut. Res. 17 (3), 688-702.

Petrovic, M., Ginebreda, A., Acuña, V., Batalla, R.J., Elosegi, A., Guasch, H., López de Alda, M. Marcé, R., Muñoz, I. Navarro-Ortega, A Navarro, E., Vericat, D., Sabater, S., Barceló, D. 2011. Combined scenarios of chemical and ecological quality under water scarcity in Mediterranean rivers. TrAC Trends Anal. Chem. 30 (8), 1269-1278.

Pickett, S.T.A., Cadenasso, M.L., Grove, J.M., Boone, C.G., Groffman, P.M., Irwin, E., Kaushal, S.S., Marshall, V., McGrath, B.P., Nilon, C.H., Pouyat, R.V., Szlaveczk, K., Troy, A Warren, P., 2011. Urban ecological systems: scientific foundations and a decade of progress. J. Environ. Manag. 92 (3), 331-362.

Pompêo, M., Padial, P.R., Mariani, C.F., Cardoso-Silva, S., Moschini-Carlos, V., Silva D.C.V.R.D., de Paiva, T.C.B., Brandimarte, A.L., 2013. Biodisponibilidade de metais no sedimento de um reservatório tropical urbano (reservatório Guarapiranga-São Paulo (SP), Brasil): há toxicidade potencial e heterogeneidade espacial? Geochim. Bras. 27 (2), 104-119.

Posthuma-Doodeman, C.J.A.M., 2008. Environmental risk limits for imidacloprid. RIVM Letter report, 601716018, 2008

Qin, H.P., Khu, S.T., Yu, X.Y., 2010. Spatial variations of storm runoff pollution and their correlation with land-use in a rapidly urbanizing catchment in China. Sci. Total Environ. 408 (20), 4613-4623.

Richardson, S.D., Kimura, S.Y., 2015. Water analysis: emerging contaminants and current issues. Anal. Chem. 88 (1), 546-582.

Rivetti, C., Campos, B., Faria, M., Català, N.D.C., Malik, A., Muñoz, I., Tauler, R., Soares, A.M.V.M., Osorio, V., Pérez, S., Gorga, M., Petrovic, M., Mastroianni, N., López de Alda, M., Masiá, A., Campo, J., Picó, Y., Guasch, H., Barceló, D., Gorga, M., 2015. Transcriptomic, biochemical and individual markers in transplanted Daphnia magna to characterize impacts in the field. Sci. Total Environ. 503, 200-212.

Rosi-Marshall, E.J., Snow, D., Bartelt-Hunt, S.L., Paspalof, A., Tank, J.L., 2015. A review of ecological effects and environmental fate of illicit drugs in aquatic ecosystems. J. Hazard. Mater. 282, 18-25.

Rubin, B.S., 2011. Bisphenol A: an endocrine disruptor with widespread exposure and multiple effects. J. Steroid Biochem. Mol. Biol. 127 (1), 27-34

SABESP, Companhia de Saneamento Básico do Estado de São Paulo, 2015a. http://www2. sabesp.com.br/mananciais/DivulgacaoSiteSabesp.aspx accessed June 2015.

Sajiki, J., Yonekubo, J., 2003. Leaching of bisphenol A (BPA) to seawater from polycarbonate plastic and its degradation by reactive oxygen species. Chemosphere 51, 55-62.

Santos, A.A., Ranzani-Paiva, M.J.T., Felizardo, N.N., Rodrigues, E.D.L., 2004. Análise histopatológica de fígado de tilápia-do-Nilo, Oreochromis niloticus, criada em tanque-rede na represa de Guarapiranga, São Paulo, SP, Brasil. Boletim do Instituto de Pesca 30 (2) 141-145.

Santos, R.M., Saggio, A.A., Silva, T.L.R., Negreiros, N.F., Rocha, O., 2015. Short-term thermal stratification and partial overturning events in a warm polymictic reservoir: effects on distribution of phytoplankton community. Braz. J. Biol. 75 (1), 19-29.

SEADE, 2015. Portal de Estadísticas do Estado de São Paulo, Fundação Sistema Estadual de Análise de Dados. Available from http://produtos.seade.gov.br/produtos/msp/index. php?tip $=$ met4\&opt $=$ s\&tema $=$ SNE\&subtema $=213$ September 2015 .

Sendacz, S., Monteiro Jr., A.J., Mercante, C.T., Menezes, L.C.B., 2005. Cargas de nutrientes (Nitrogênio e Fósforo) na bacia do Alto Tietê (Cabeceiras Guarapiranga) no Sistema Produtor Alto Tietê. NEGOWAT PROJECT, São Paulo.

Shiromoto, J., Leitão, J.C., Tomoyuki Tsutiya, M., 2005. Operação do sistema taquacetuba para a transferência de água do reservatório Billings para represa Guarapiranga-
Região Metropolitana de São Paulo. Saneamento ambiental Brasileiro: Utopia ou realidade?Associaçao Brasileira de Engenharia Sanitaria e Ambiental, Rio de Janeiro, Rio de Janeiro, Brazil, pp. 1-12.

Smith, V.H., Schindler, D.W., 2009. Eutrophication science: where do we go from here? Trends Ecol. Evol. 24 (4), 201-207.

Smith, V.H., Tilman, G.D., Nekola, J.C., 1999. Eutrophication: impacts of excess nutrient inputs on freshwater, marine, and terrestrial ecosystems. Environ. Pollut. 100 (1), $179-196$.

Sodré, F.F., Locatelli, M.A.F., Jardim, W.F., 2010a. Occurrence of emerging contaminants in Brazilian drinking waters: a sewage-to-tap issue. Water Air Soil Pollut. 206 (1-4), 57-67.

Sodré, F.F., Pescara, I.C., Montagner, C.C., Jardim, W.F., 2010b. Assessing selected estrogens and xenoestrogens in Brazilian surface waters by liquid chromatography-tandem mass spectrometry. Microchem. J. 96 (1), 92-98.

Souza Beghelli, F.G., Frascareli, D., Pompêo, M.L.M., Moschini-Carlos, V., 2016. Trophic state evolution over 15 Years in a tropical reservoir with low nitrogen concentrations and cyanobacteria predominance. Water Air Soil Pollut. 227 (3), $1-15$.

Suárez-Serrano, A., Alcaraz, C., Ibanez, C., Trobajo, R., Barata, C., 2010. Procambarus clarkii as a bioindicator of heavy metal pollution sources in the lower Ebro River and Delta. Ecotoxicol. Environ. Saf. 73 (3), 280-286.

Swiss Centre for Applied Ecotoxicology (Ecotox Centre), 2015. Proposals for acute and chronic quality standards. http://www.ecotoxcentre.ch/expert-service/qualitystandards/proposals-for-acute-and-chronic-quality-standards/ accessed Oct 25, 2015.

Teuten, E.L., Saquing, J.M., Knappe, D.R., Barlaz, M.A., Jonsson, S., Björn, A., Rowland, S.J., Thompson, R.C., Galloway, T.S., Yamashita, R., Ochi, D., Watanuki, Y., Moore, C., Viet, P.H., Tana, T.S., Prudente, M., Boonyatumanond, R., Zakaria, M.P., Akkhavong, K., Ogata, Y., Hirai, H., Iwasa, S., Mizukawa, K., Hagino, Y., Imamura, A., Saha, M., Takada, H., 2009. Transport and release of chemicals from plastics to the environment and to wildlife. Philosophical Transactions of the Royal Society B: Biological Sciences 364 (1526), 2027-2045.

Thuyet, D.Q., Jorgenson, B.C., Wissel-Tyson, C., Watanabe, H., Young, T.M., 2012. Wash off of imidacloprid and fipronil from turf and concrete surfaces using simulated rainfall. Sci. Total Environ. 414, 515-524.

Tixier, C., Singer, H.P., Oellers, S., Müller, S.R., 2003. Occurrence and fate of carbamazepine, clofibric acid, diclofenac, ibuprofen, ketoprofen, and naproxen in surface waters. Environ. Sci. Technol. 37 (6), 1061-1068.

Toledo Jr., A.P., Talarico, M., Chinez, S.J., Agudo, E.G., 1983. A Aplicacão de Modelos Simplificados para a Avaliacão de Processo da Eutrofizacão em Lagos e Reservatórios Tropicais. Anais do $12^{\circ}$ Congresso Brasileiro de Engenharia Sanitária. Camboriú. Associacão Brasileira de Engenharia Sanitária, Camboriú (SC), p. 34

Tundisi, J.G., Matsumura-Tundisi, T., 2003. Integration of research and management in optimizing multiple uses of reservoirs: the experience in South America and Brazilian case studies. Hydrobiologia 500, 231-242.

Tundisi, J.G., Matsumura-Tundisi, T., Tundisi, J.E.M., 2008. Reservoirs and human wellbeing: new challenges for evaluating impacts and benefits in the neotropics. Braz. J. Biol. 68 (4), 1133-1135

Tundisi, J.G. Rocha, O., Matsumura-Tundisi, T., Braga, B., 1998. Reservoir management in South America. Int. J. Water Resour. Dev. 14, 141-155.

Turner, R.K., Daily, G.C., 2008. The ecosystem services framework and natural capital conservation. Environ. Resour. Econ. 39 (1), 25-35.

Valderrama, J.C., 1981. The simultaneous analysis of total nitrogen and total phosphorus in natural waters. Mar. Chem. 10 (2), 109-122.

Van Dijk, T.C., Van Staalduinen, M.A., Van der Sluijs, J.P., 2013. Macro-invertebrate decline in surface water polluted with imidacloprid. PLoS One 8 (5), e62374.

Vörösmarty, C.J., McIntyre, P.B., Gessner, M.O., Dudgeon, D., Prusevich, A., Green, P., Glidden, S., Bunn, S.E., Sullivan, C.A., Davies, P.M., 2010. Global threats to human water security and river biodiversity. Nature 467 (7315), 555-561.

Wang, Y., Wang, Q., Hu, L., Lu, G., Li, Y., 2015. Occurrence of estrogens in water, sediment and biota and their ecological risk in Northern Taihu Lake in China. Environ. Geochem. Health 37 (1), 147-156.

Wenzel, A. Schlich, K., Shemotyuk, L, Nendza, M., 2014. Revision Der Umweltqualitätsnormen Der Bundes-Oberflächengewässerverordnung Nach Ende Der Übergangsfrist Für Richtlinie 2006/11/EG Und Fortschreibung Der Europäischen Umweltqualitätsziele Für Prioritäre Stoffe. Report UBA-FB 00 Revision. Dessau, Deutschland.

Whately, M., Cunha, P.M.D., 2006. Guarapiranga 2005: como e por que São Paulo está perdendo este manancial; resultados do diagnóstico socioambiental participativo da Bacia Hidrográfica da Guarapiranga. Guarapiranga 2005: como e por que São Paulo está perdendo este manancial; resultados do diagnóstico socioambiental participativo da Bacia Hidrográfica da Guarapiranga. Instituto Socioambiental.

WHO, 2011. Guidelines for Drinking-Water Quality. 4th ed. World Health Organization, Switzerland.

Wright-Walters, M., Volz, C., Talbott, E., Davis, D., 2011. An updated weight of evidence approach to the aquatic hazard assessment of bisphenol $\mathrm{A}$ and the derivation a new predicted no effect concentration (PNEC) using a non-parametric methodology. Sci. Total Environ. 409 (4), 676-685.

Xu, Y., Luo, F., Pal, A., Gin, K.Y.H., Reinhard, M., 2011. Occurrence of emerging organic contaminants in a tropical urban catchment in Singapore. Chemosphere 83 (7), 963-969.

Xue, N., Xu, X., Jin, Z., 2005. Screening 31 endocrine-disrupting pesticides in water and surface sediment samples from Beijing Guanting reservoir. Chemosphere 61 (11), 1594-1606. 
Yan, Z., Yang, X., Lu, G., Liu, J., Xie, Z., Wu, D., 2014. Potential environmental implications of emerging organic contaminants in Taihu Lake, China: comparison of two ecotoxicological assessment approaches. Sci. Total Environ. 470, 171-179.

You, L., Nguyen, V.T., Pal, A., Chen, H., He, Y., Reinhard, M., Gin, K.Y.H., 2015. Investigation of pharmaceuticals, personal care products and endocrine disrupting chemicals in a tropical urban catchment and the influence of environmental factors. Sci. Total Environ. 536, 955-963.

Zarfl, C., Lumsdon, A.E., Berlekamp, J., Tydecks, L., Tockner, K., 2015. A global boom in hydropower dam construction. Aquat. Sci. 77 (1), 161-170. 